\title{
DENIS O'BRYEN: (NOMINALLY) SECOND MARSHAL OF THE VICE-ADMIRALTY COURT OF THE CAPE OF GOOD HOPE, 1806-1832
}

\section{JP van Niekerk***}

\section{Introduction}

The first marshal of the Vice-Admiralty Court at the Cape of Good Hope having been historically a controversial figure, ${ }^{1}$ I was greatly surprised when it turned out that the second and long-serving holder of the office, Denis O'Bryen, ${ }^{2}$ was likewise considered to have been a personality of some note. An Irish-born dramatist, political

1 See my "George Rex of Knysna: A civil lawyer from England and first marshal of the ViceAdmiralty Court of the Cape of Good Hope, 1797-1802" (2010) 16(1) Fundamina (editio specialis: Libellus ad Thomasium. Essays in Roman Law, Roman-Dutch Law and Legal History) 486-513.

2 There are also alternative spellings of his name (Dennis) and surname (O'Brien, O'Bryne and O'Bryan), but O'Bryen himself seems to have preferred the (now) more unusual version.

* $\quad$ Professor, Department of Mercantile Law, School of Law, University of South Africa.

** I should like to dedicate this article to the memory of my former colleague, AB (Basil) Edwards, 14 Nov 1930-15 Jan 2014, who wrote so engagingly about Mr Blane's involvement in an episode of jurisdictional head-butting: see "A conflict of jurisdiction" (1972) 12(1) Codicillus 42-43 and further nn 23 and 183-184 below.

\section{UNISA $\cong$}

Fundamina

Volume 21 | Number 1 | 2015

pp 142-184
Doi: $10.17159 / 2411-7870 / 2015 / v 21 n 1 a 8$ Print ISSN 1021-545X/ Online ISSN 2411-7870

(C) Unisa Press 
pamphleteer, and confidant and aide to the prominent Whig politician Charles James Fox, his life merited a brief entry in the British Dictionary of National Biography.

However, I was to discover that there was more to his appointment as Admiralty marshal at the Cape than at first appeared. ${ }^{3}$

\section{Background}

\section{The establishment and jurisdiction of the second Cape Vice-Admiralty Court}

When the British re-occupied the settlement at the Cape of Good Hope in January 1806, they soon recognised the need to re-establish a local Vice-Admiralty Court; the one that had operated during the First Occupation had been closed down in $1803 .{ }^{4}$ In the absence of such a court, several Anglo-Dutch and some purely British prize issues flowing from the Occupation ${ }^{5}$ and those likely to arise locally from the war being waged against France at that time, could only be resolved inconveniently and at great expense by the Court of Admiralty in London. ${ }^{6}$

The instructions issued in August 1806 to the first permanent governor of the Cape after re-occupation, the Earl of Caledon, referred to his receiving an Admiralty Commission constituting him Vice Admiral of the settlement at the Cape. ${ }^{7}$ The royal instructions, issued in September 1806 by Letters Patent under Privy Seal to the Lords of Admiralty, to appoint a Vice Admiral at the Cape explained that it would be advantageous "to have a Court of Vice Admiralty settled there". It specifically authorised and empowered the Lords to do so (it appeared that they might have

3 I was greatly assisted in my search for the story behind O'Bryen's appointment by correspondence during Apr 2014 with Prof David O'Shaughnessy, School of English, Trinity College Dublin. He provided me with valuable background information on O'Bryen's early life as well as a copy of a draft piece entitled “Making a play for patronage: Dennis O'Bryen's A Friend in Need Is a Friend Indeed (1783)" subsequently appeared in (2015) 39 Eighteenth-Century Life at 183-211.

4 See AB Edwards The History of South African Law: An Outline (Durban, 1996) at 75 n 233 and 79 n 249; DH van Zyl Geskiedenis van die Romeins-Hollandse Reg (Durban, 1983) at 449.

5 Some of these were eventually determined by the London Court of Admiralty in 1809 (see, eg, George McCall Theal (ed) Records of the Cape Colony 36 vols (Cape Town, 1897-1905) (hereafter $R C C$ ) vol 7 at 350-351), but even by 1819 others had not yet been finally resolved (idem vol 12 at 183).

6 See, eg, idem vol 5 at 413, concerning the ship Fortuna, sailing under Mecklenburg colours en route to Batavia. She was detained in Table Bay in May 1806 and her papers, together with other supporting documentation, were "transmitted ... to His Majesty's Court of Admiralty [in London] for adjudication". Subsequently Sir David Beard, commandant at the Cape, was compelled to deny in a letter to the secretary of state Viscount Castlereagh that he had taken it upon himself to decide this prize cause and to appropriate the prize property (idem vol 6 at 158).

Idem vol 6 at 15-16. 
had no such power in respect of newly conquered territories) by appointing a Vice Admiral and also a Vice-Admiralty judge and other proper officers required for the functioning of a Court of Vice Admiralty at the Cape, and to issue such commissions as would be necessary. ${ }^{8}$

The first Admiralty judge to be appointed and sent out from London after the Second British Occupation of the Cape was Winchcombe Henry Hartley, who served from 1806-1810. ${ }^{9}$ The second person to occupy the office was George Kekewich, at the time the King's advocate in the settlement. He sat as judge, at first temporarily, ${ }^{10}$ and then permanently, from June 1811 until $1827 .{ }^{11}$ Although at times

$8 \quad$ Idem vol 6 at 31-32.

9 Hartley, a barrister and fellow of the Honorable Society of Lincoln's Inn and residing in Great Russell Street in Bloomsbury, was appointed to the post in Nov 1806, but only arrived at the Cape the following year (idem vol 6 at 51), on the same ship as Alexander du Pré, Earl of Caledon, the first (permanent) governor from May 1807 to Jul 1811. Although his annual salary was £6 000 (paid out of the penalties and forfeitures levied by his Court, or, if that was insufficient, out of the fund arising from the sale of old naval stores), Hartley soon complained to Castlereagh about his income. He had already requested an appointment in any other vacant office in view of the fact that his salary was smaller than that of his predecessor or of Admiralty judges elsewhere (idem vol 6 at 64). He had also signed a memorial to governor Caledon requesting that civil servants be paid from the date of their appointment in England rather than only from the date of their arrival at the Cape (see Peter Philip British Residents at the Cape 1795-1819. Biographical Records of 4800 Pioneers (Cape Town, 1981) at 168). In 1808, when Hartley returned temporarily to England "for the arrangement of some Matters essentially affecting his Office", the King's advocate, Andrew Cassels, acted in his place as Admiralty judge despite governor Caledon questioning whether such an absence or substitution was permissible (see Theal $R C C$ (n 5) vol 6 at 235-237). The view of the law advisor in London, in the person of Sir (Dr) John Nicoll, was that the judge of the Cape Vice-Admiralty Court did have the right to absent himself without the governor's permission, and that according to the express terms of his patent he could appoint a deputy or surrogate, in which appointment the governor's acquiescence was unnecessary (idem vol 6 at 303-304 and 311). Cassels' temporary appointment came at a time when he was seriously ill and he died shortly afterwards, in Jan 1809 (Philip at 62; Theal RCC (n 5) vol 6 at 387-388 and 408 and vol 7 at 18-19, 302 and 492).

10 In Jun 1810 the appointment was announced of Kekewich, "Surrogate Judge" of the ViceAdmiralty Court, as assessor to the court of Appeals in criminal cases (Theal RCC (n 5) vol 7 at 287) and in a letter written by Governor Caledon in the same month, he is referred to as the King's advocate and "acting Surrogate" in the Admiralty Court (idem vol 7 at 301).

11 Kekewich (1778-1862), also a barrister in the High Court of Chancery (he compiled A Digested Index to the Earlier Chancery Reports (London, 1804)) and member of the Honorable Society of Lincoln's Inn, arrived at the Cape in Dec 1809 (having been appointed in Jun) as the King's advocate in the settlement. In 1810, he was also appointed as an assessor in civil and criminal cases in the Court of Appeals. His second marriage, in Jan 1812, was to Catharina Cornelia de Waal. Her younger sister was married to Thomas Rowles, a practitioner (proctor and, more specifically, from 1807, the King's proctor) in the local Vice-Admiralty Court from 1800 (he was one of the few barristers to practise in the Court during both British occupations), also active in other courts (including the Court of Appeals), and on occasion also acting judge during his brother-in-law's absences from the colony (see, eg, Theal RCC (n 5) vol 31 at 364, 371 and 372 and vol 32 at 181 and 185). On Rowles, see Philip (n 9) at 365. Upon the establishment of 
the focus of controversy, ${ }^{12}$ the Court was never really busy ${ }^{13}$ and the possibility of its discontinuance was even raised. ${ }^{14}$

Upon the creation of the new Cape Supreme Court in $1828,{ }^{15}$ the Chief Justice the first appointee being Sir John Wylde ${ }^{16}$ - was also appointed to serve as the judge

the new Supreme Court in 1828, and the appointment of Chief Justice Wylde as the Admiralty judge, Kekewich (who was not then also appointed as Admiralty judge, as Van Zyl (n 4) at 451 would have it) became the third puisne judge in the new Court (alongside Menzies and Burton), in which capacity he served until his retirement and return to England in 1843. On Kekewich, see Philip (n 9) at 216-217; AA Roberts A South African Legal Bibliography (Pretoria, 1942) at 367; Stephen Girvin "The establishment of the Supreme Court of the Cape of Good Hope and its history under the chief justiceship of Sir John Wylde. Parts I and II" (1992) 109 SALJ 291-306 and 652-665 at 303-304 and 654-655 and 664 respectively (Girvin observing that Kekewich was the weakest of the four appointments to the Cape bench and that his appointment was anomalous and disappointing "as he had been criticized in his previous position as judge of the Vice-Admiralty court and assessor").

12 In 1814, eg, allegations were levelled at the Court about its perceived improper conduct in slave cases. It was alleged that it had released arrested slavers on their payment of sums of money; had granted local inhabitants the slaves taken from them and, in one case, had withheld a ship's papers until payment of a "gratuity" to the Court even though there was no charge against her. In correspondence between Kekewich and the colonial government, he refuted these "unsubstantiated charges" vigorously (Theal $R C C$ (n 5) vol 9 at 487-490).

13 On the death of Thomas Rowles in 1826, the Court of Appeals was left without a secretary or an assessor in civil cases. Governor Somerset temporarily appointed Kekewich - who had served in that capacity in criminal cases - to the vacancy (idem vol 26 at 72). The reasons for his permanent appointment were that he was one of few English lawyers in the colony and that although he served in the Vice-Admiralty Court, other tasks, including the proper formulation of local ordinances, could be assigned to him since he had "little or nothing to do in his Court". However, Kekewich declined to offer his assistance in this regard and the appointment of someone from England was requested (idem vol 26 at 407-408).

14 Especially after the Peace Treaty of Amiens in 1814, the Court's principal jurisdiction, that in prize matters, became largely dormant, leading the then governor Lord Charles Somerset to suggest in Nov 1816 that the Vice-Admiralty Court might be discontinued at the Cape (idem vol 11 at 159). However, London thought otherwise, referring, somewhat obliquely, to the Court's importance to naval officers and men (idem vol 11 at 214 and 330). This left Somerset still dissatisfied and in May 1817 he noted the absence of a pertinent reply to his suggestion "relative to the Court of Vice Admiralty here, for the continuance of which I can see no necessity" (idem vol 11 at 336).

15 See, generally, Girvin (n 11).

16 Wylde (1781-1859) was Chief Justice and therefore Admiralty judge until his death. He had been judge-advocate of New South Wales from 1816 and had also been appointed to the ViceAdmiralty Court there. On his appointment as Chief Justice of the Cape Supreme Court and also, separately, as judge of the local Vice-Admiralty Court (see, eg, Theal RCC (n 5) vol 32 at 25, 152 and 171), Wylde wrote to Viscount Goderich, the secretary of state, in Aug 1827 requesting that he be allowed the fees formerly payable to the Admiralty judge. He mentioned that the business of the Vice-Admiralty Court involved "delicate questions on the subject of slaves" and amounted to a "material addition" to his already extensive duties as Chief Justice. He also referred to the fact that chief justices in other colonies received separate remuneration for performing the duties of Admiralty judge. This request, together with others, was ultimately refused (see idem vol 32 at 252-254). Although he enjoyed good health for most of his long legal career, the first signs of 
in the local Vice-Admiralty Court. In 1891, when Vice-Admiralty courts were finally abolished, ${ }^{17}$ Lord Henry de Villiers was accordingly the last specifically appointed Admiralty judge at the Cape.

At the risk of unnecessary repetition, it may be apposite briefly to identify the main features of Vice-Admiralty courts, including the one at the Cape of Good Hope. ${ }^{18}$

First, they were imperial (British) and not colonial courts and have to be distinguished, in the case of the Cape, from the local Council of Justice (Raad van Justitie) and its successor, the Cape Supreme Court. The judge of the local ViceAdmiralty Court was therefore not, as such, a colonial judge, even if, subsequently, the local Chief Justice was also appointed by the British Admiralty as the local Admiralty judge.

Secondly, the Cape Vice-Admiralty Court did not, like the Council of Justice and later the Supreme Court, apply local Roman-Dutch law, but English law. More particularly, it applied English maritime and Admiralty law that, even though it often displayed its civil-law origins, certainly no longer resembled the applicable local law.

Thirdly, Vice-Admiralty courts exercised a permanent instance jurisdiction of variable scope at different times over various questions of maritime law such as the carriage of goods by or collisions at sea, or the claims of seamen and salvors. In addition, it could also exercise a prize jurisdiction, which was unusual in that it was limited in both scope and duration by the terms of the Commission conferring the jurisdiction on it. ${ }^{19}$ A Prize court, therefore, was simply an Admiralty (or Vice-Admiralty) court exercising, for the time being, a specially conferred prize jurisdiction.

Fourthly, the permanent Cape Vice-Admiralty Court should be distinguished from an ad hoc, temporary court, generally known as a Piracy Court or Commission Court (because it was constituted in every case by a Commission ${ }^{20}$ and comprised

his failing health came in his seventy-fifth year, in Sep 1855, when Wylde suffered a stroke while delivering judgment in a slave-trading case as Admiralty judge. On Wylde, see Roberts (n 11) at 384; Girvin (n 11) at 295-298 and 662; and F St LS "Sir Johyn Wylde" (1933) 50 SALJ 284-297.

17 See, further, $\mathrm{n} 220$ below.

18 For more detail, with references, see Van Niekerk (n 1) at 499-504.

19 The British authorities seem to have been caught unawares by the War of 1812 with the United States. As a result, the detention of American ships at the Cape in 1813 caused "considerable embarrassment and difficulty" because the local Vice-Admiralty Court received no orders (ie, from a Commission conferring prize jurisdiction on it) enabling it to proceed to their condemnation (Theal RCC (n 5) vol 9 at 176-177 and 222).

20 The absence of such a Commission and the Vice-Admiralty Court's perceived lack of criminal jurisdiction caused severe problems and heated debate in 1825. The reason was that British seamen and others accused of mutiny or murder at sea could be, and were, tried by the local colonial court applying "Dutch law" rather than by a (local) British court applying English criminal law (see, eg, Theal RCC (n 5) vol 23 at 9, 451-454, 471-472, 481, 485-486 and 497-498). By Apr 
a body of Commissioners) but also confusingly referred to simply as an Admiralty Court. ${ }^{21}$ This Court had criminal jurisdiction over (serious) offences committed on the high seas, including, therefore, piracy, and was made up of seven Commissioners, the judge of the local Vice-Admiralty Court being but one of the members.

Fifthly, despite its name and the involvement of the Admiralty in its establishment and the appointment of its judges, a Vice-Admiralty court was not a naval court. In this respect, therefore, it should be distinguished from naval courts-martial, which had jurisdiction over naval (as opposed to maritime) matters such as those relating to the discipline of officers and seamen of the Royal Navy.

Despite the differences between the Cape Vice-Admiralty Court and the local colonial courts - first, the Council of Justice and later the Cape Supreme Court one common but complicating factor was that their jurisdictions overlapped. Some maritime matters could be heard in either court and claimants could often choose in which one to lodge their claims. The success or failure of those claims could well depend on their choice because the courts applied different laws and followed distinct procedures. In addition, if there were several claimants, the same matter could even be heard simultaneously but separately in the two courts. ${ }^{22}$

Even at an early stage many instances of jurisdictional clashes between the two courts were brought to the attention of the authorities, ${ }^{23}$ but the problem was

1826, the authorities in London acknowledged "that a competent jurisdiction should be forthwith established" at the Cape and instructed the Admiralty to issue an appropriate Commission for that purpose (idem vol 26 at 263). However, that seems not to have happened. In Aug 1827 the report of the Commission of Enquiry into the administration of justice at the Cape observed in respect of criminal law and jurisprudence that the criminal jurisdiction exercised by the Council of Justice over crimes committed in the colony had been extended, on rather doubtful authority, to those committed on ships when at sea or anchored in the harbours of the colony, and that no Commission of Piracy had yet been issued superseding that jurisdictional cognizance (idem vol 33 at 53).

21 See Van Zyl (n 4) at 445.

22 To clarify, the Vice-Admiralty Court exercised not only concurrent jurisdiction in some matters, but also a separate and exclusive jurisdiction in others, (see, eg, the instructions to the Commission of Enquiry into the Cape in Theal RCC (n 5) vol 15 at 239). The same was, of course, true of the Council of Justice.

23 In May 1808, eg, the Vice-Admiralty Court in the person of its deputy marshal and the Council of Justice represented by the sheriff were involved in a quite undignified judicial boat race across Table Bay when both attempted to be the first to arrest, and hence assert jurisdiction over, a suspected slaver, the Portuguese ship Rosalia. On arriving at the ship, the deputy marshal pushed the sheriff away and was thus first on board, but each claimed and, assuming a plea of prior capture, instituted proceedings against the ship in his own court. The Council of Justice complained to the governor that the Admiralty marshal had impeded the sheriff in the execution of his duties. Ultimately the Vice-Admiralty Court ordered the release of the Rosalia while the Council of Justice condemned her, but after an investigation, decided not to proceed any further (see Theal $R C C$ (n 5) vol 6 at 330-331; Edwards (n 4); and HB Giliomee "Die administrasietydperk van Lord Caledon 1807-1811" in (1966) no 2 Archives Year Book for South African History 213-366 at 254255 (referring to the clash as a "komiese situasie" causing the governor "groot verleentheid"). 
not addressed and continued to arise from time to time. ${ }^{24}$ When the issue was brought to their attention in 1820, the view of the authorities in London was that the Vice-Admiralty Court's jurisdiction over certain matters was settled and could not be contested by the local colonial court, even if it did possess an overlapping jurisdictional power. In short, the prior jurisdiction of any of the two courts could not be superseded. While that seemingly settled the matter in practice, ${ }^{25}$ it did not eliminate the continuing concurrency of jurisdiction of the two courts in appropriate cases. ${ }^{26}$ A further suggestion, in 1822, that a newly reformed colonial court should be vested with Admiralty jurisdiction "by which means past collisions would be avoided", ${ }^{27}$ was not fully realised when the Cape Supreme Court was established in $1827 .{ }^{28}$ The Vice-Admiralty Court continued to exist and exercise its distinct jurisdiction as before, but at least now the Chief Justice, who was also as such the Admiralty judge, could himself properly manage any jurisdictional collisions. The conflict continued even when, in 1891, the local colonial court was vested with Admiralty jurisdiction, since that court had to apply different laws, depending on which jurisdiction (civilian or Admiralty) it was exercising. ${ }^{29}$

24 For instance, in 1818, in connection with the jurisdiction over slaves either taken from captured slavers or abandoned by the masters of such ships (see, eg, the correspondence in Theal $R C C$ (n 5) vol 11 at 475-480 and vol 12 at 1-4). In 1821, again, the Council of Justice's John Truter complained to the governor about the Vice-Admiralty Court's exercise of its jurisdiction. In consequence, the deputy marshal was prevented from advertising the sale of a vessel that had already been sold by order of the Council of Justice. In response, Admiralty Judge George Kekewich complained about this "prohibition", causing the governor to bring the matter to the attention of the authorities in London, because it not only had judicial implications - appeals, eg, went to different courts - but also financial implications for the colonial government which would get nothing out of Admiralty confiscations but one-third of the value of Council of Justice sales (see idem vol 13 at 371-375, 377-384, 421-436, 441-442, 451-453 and 464).

25 In evidence given before the Commission of Enquiry into the judicial system at the Cape in Aug 1825, John Truter of the Council of Justice explained, on the issue of the jurisdictional conflict, that "at present a mutual understanding prevails between myself and the Judge of the Court of Vice Admiralty that we should prevent any open conflict of our jurisdictions in these cases by private conference at the outset" (idem vol 33 at 262-263).

26 See idem vol 13 at 486-487 and vol 14 at 117-118.

27 Idem vol 14 at 86 in a memorandum on the reformation of the judicial structure at the Cape, and idem vol 14 at 372 where a letter from Bathurst referred to "the tendency to collision, from a concurrency of Jurisdiction, between the present Colonial, and Vice Admiralty Courts at the Cape". The solution recommended by the Commission of Enquiry in 1826 was that the commencement of action in either of the courts should be sufficient a bar to all other proceedings for the same cause of action (idem vol 28 at 9-10 and 21-22).

28 There is no mention of the Vice-Admiralty Court or of Admiralty jurisdiction in the Charter of Justice of 1827 (idem vol 32 at 274-292). The reason is readily apparent: the Vice-Admiralty Court was not a colonial court within the purview of the Commission appointed to reform the local judicial system.

29 See, further, Christopher Forsyth "The conflict between modern Roman-Dutch law and the law of Admiralty as administered by South African courts" (1982) 99 SALJ 255-270. 
The matter was finally resolved only in the late twentieth century when the law to be applied in the resolution of particular maritime issues was prescribed by statute, a compromise solution not acceptable to all, given that South African law, drawing on its subsidiary common law, was retained in respect of some maritime matters. ${ }^{30}$

\section{The Admiralty marshal}

After the judge and the registrar, the Admiralty marshal was the most important official in any Vice-Admiralty court and, by the nature of his duties, also the one most in the public eye. ${ }^{31}$

The marshal's main duty was to serve Admiralty processes. After a plaintiff had met the necessary requirements regarding the nature and, in the case of an action in rem, the object of his claim, the Court's registrar issued a warrant to the marshal directing him to arrest the ship or cargo in question or, in the more unusual case of an action in personam, to serve it upon the defendant. The marshal or his deputy served the warrant, in the case of a vessel, "in the time-honoured manner of exhibiting the original and holding it to the mainmast, then nailing a copy in its place". ${ }^{32} \mathrm{He}$ then executed a certificate of service, commonly called the marshal's return, which was filed in the Court's registry together with the original warrant. In the case of an action in personam, where the warrant was for the arrest of a person, the marshal exhibited it and took the defendant into custody, from which he was released upon the provision of security. ${ }^{33}$

Once a ship was arrested, the marshal, if necessary left a member of his staff on board to prevent her sailing from the Court's jurisdiction and to protect her from damage or pillage while in custody. In the case of arrested cargo, the marshal had to see to its discharge and warehousing. Failing in his duty to protect arrested property from damage could lay the marshal open to a claim in damages. ${ }^{34}$

30 See s 6(1) of the Admiralty Jurisdiction Regulation Act 105 of 1983 and, eg, John Hare Shipping Law \& Admiralty Jurisdiction in South Africa 2 ed (Cape Town, 2009) at 14-29.

31 See, further, FL Wiswall The Development of Admiralty Jurisdiction and Practice since 1800. An English Study with American Comparisons (Cambridge, 1970) at 12-13, 16, 47-48 and 121; ES Roscoe A Treatise on the Jurisdiction and Practice of the Admiralty Division of the High Court of Justice ... (London, 1878) at 7.

32 Wiswall (n 31) at 13. Towards the end of the nineteenth century, it became the practice for the warrant of arrest to be served in actions in rem by the plaintiff's legal representative. However, in The Solis (1885) 5 Aspinall's Maritime Law Cases 368, the Court observed in passing that only the marshal had the right to board a ship and nail a writ of summons in rem to the mast and that the representative might be trespassing if he tried to do so.

33 Later, the defendant was merely served with an instrument called a "monition", addressed to the marshal and commanding him to cite the defendant personally and "admonish" him to appear in court (Wiswall (n 31) at 63).

34 See The Hoop (1801) 4 C Rob 145, 165 ER 566 for an instance of a successful claim against the Admiralty marshal for the compensation of loss sustained by pillage and theft whilst the property 
Once a ship or other maritime property had been condemned by the Admiralty court, the marshal had the duty of arranging for a sale in execution. He had to appraise, advertise and then sell the property by auction. Before 1840, the Admiralty marshal was not salaried, but received his income from fees, including a brokerage fee that was customarily charged on the sale of maritime property.

The marshal also had other public duties, including appearing at official and public ceremonies - such as piracy executions or judicial processions - where he bore the Court's silver oar mace. ${ }^{35}$

\section{O'Bryen's early life}

Denis O'Bryen ${ }^{36}$ was born in Ireland in 1755 . He qualified as a surgeon, moved to London and in the 1780s relinquished the practice of his profession and turned his hand to writing and a political career. As will be apparent, these two pursuits were closely linked. ${ }^{37}$

He first gained notoriety with the publication, in 1782, of a satirical and sarcastic pamphlet entitled A Defence of ... the Earl of Shelburne, from the Reproaches of His Numerous Enemies ... ${ }^{38} \mathrm{He}$ had written it anonymously but in the hope of preferment from one (the Rockingham) faction of the liberal Whig party and of gaining the attention of one of the party's rising stars, Charles James Fox. It was an immediate success, selling out quickly and necessitating several reprints. In a portent of what

was in his custody. The Court rejected the marshal's defence that he was unable to protect the property properly because his fees were too small. The Court thought that if arrested property were lost or damaged, the marshal had at least to show that this had not been through any default of his own. If indeed his fees were insufficient to enable him to provide proper security, this should be raised with relevant authorities, but could not be relied on as a defence.

35 See my "The story of the silver oar maces of the Vice-Admiralty Court of the Cape of Good Hope" (2012) 18(1) Fundamina 135-173.

36 For general biographical details on him, see Thompson Cooper sv "O'Bryen, Dennis" in Dictionary of National Biography vol 41 (London, 1895) 340 at 340; Gail Baylis sv "O'Bryen, Dennis" in Oxford Dictionary of National Biography (2004, online ed 2007, accessed 28 Aug 2013); Biographical Dictionary of the Living Authors of Great Britain and Ireland ... (London, 1816) $s v$ "O'Bryen Denis" at 255-256; and O'Shaughnessy (n 3).

37 O'Shaughnessy (n 3) mentions his blurred transition from political pamphleteer to confidant to the upper echelons of Whig society, and the complicated story of how he made his way as a bankrupt Irish immigrant in a class-conscious metropolitan London.

38 The pamphlet attacked Irish-born William Petty, the Earl of Shelburne, secretary of state from Mar to Jul 1782 and then, succeeding the Marquess of Rockingham, Prime Minister until Apr 1783 during the short-lived Whig administration and the last months of the American War of Independence. Shelburne was, somewhat controversially and in opposition to other Whig luminaries, including Charles James Fox, a friend of America with whom he secured peace. The pamphlet provoked a reply from Petty entitled A Short but Serious Reply to the Author of A [Mock] Defence of the Earl of Shelburne ... (London, 1782). 
was to transpire later in his life, it brought O'Bryen "a secret pension" from the Duke of Portland in April 1783. ${ }^{39}$

Next came his only play, the comedy A Friend in Need is a Friend Indeed, performed nine times at the Haymarket Theatre in London during July and August 1783. Further performances were shelved when O'Bryen fell out publicly with the theatre's manager over financial arrangements. Although unfavourably reviewed and never printed, it did serve O'Bryen well, also financially, given that he had been declared bankrupt in 1780. Containing several "caricatural allusions" to and in defence of the controversial Charles James Fox, it "facilitated his rise to a position of substantial political influence in London" and, more particularly, in Whig inner circles. ${ }^{40}$ It was a further attempt to gain the patronage of Fox, a prominent Whig politician, leader and statesman at the time. The latter's hedonistic lifestyle of drinking, gambling and womanising, ${ }^{41}$ as well as his opposition to the American war and support of the French revolution, made Fox a controversial public figure. ${ }^{42}$ However, as we shall see, O'Bryen's constant support of Fox was to prove fruitful.

In the course of the following decades, O'Bryen wrote and published various works, many of a political nature and showing his liberal alliances. These include A Gleam of Comfort to This Distracted Empire, demonstrating the Fairness and reasonableness of national Confidence in the present Ministry ... (1784), another ironical work on and critique of the Tory government that had taken over from the Whigs. This government was headed by William Pitt the Younger, an arch rival of Fox. Another work was $A$ View of the Treaty of Commerce with France, signed ... . September 20, 1786 ... (1787) concerning a treaty signed by the Pitt administration. In

39 Ralph A Manogue "James Ridgway and America" (1996) 31 Early American Literature 264-288 at 265. Portland succeeded Shelburne and served as Whig Prime Minister from Apr to Dec 1783.

40 On the play and O'Bryen's intention of using it to gain political advancement, see, especially, O'Shaughnessy (n 3).

41 During the 1780s and 1790s, Whig supporters met at Devonshire House, the West-End home of Georgiana Cavendish, the Duchess of Devonshire, who was also said to have had an affair with Fox of whom she was at least a close friend (see, generally, Amanda Foreman Georgiana, Duchess of Devonshire (London, 1999) and, also for a general background, Arthur Aspinall Lord Brougham and the Whig Party (London, 1927)).

42 Elected to Parliament in 1768, Fox gradually gravitated to the radical Whig party in the 1770s. When the reformist Rockingham administration came to power in Mar 1782, Fox became secretary of state for foreign affairs and, with Lord North, leader of the House of Commons in 1783. The Fox-North coalition was in office from Mar to Dec 1783, when it was defeated in the House of Lords after royal interference, the King nominating William Pitt as Prime Minister. As a result of Fox's opposition to measures Pitt sought to push through in the House of Commons, Parliament was dissolved in Mar 1784. Fox lost the election and Pitt was returned with a substantial majority. The surviving supporters of the Whig party increasingly called themselves Foxite, after the leader of the most important faction, rather than Whig. In the 1790s, Fox continued opposing the curtailment of civil liberties by the Pitt government. On Fox (1748-1806), see LG Mitchell sv "Fox, Charles James" in Oxford Dictionary of National Biography (2004, online ed 2007, accessed 9 Apr 2014). 
1788, upon King George III's illness, O'Bryen anonymously published The Prospect before Us, being a Series of Papers upon the Great Question. The "great question" was the regency crisis, which continued from October 1788 to March 1789. Not surprisingly, O'Bryen supported the demands of the Prince of Wales that he be given full rights of regency. The prince was a friend and gambling companion of Fox, and the latter's support of parliamentary reform and a curtailment of executive and monarchial power had resulted in deep animosity between Fox and the King. ${ }^{43}$

In addition, O'Bryen was an irrepressible writer of letters to newspapers on various topical and invariably political issues, so much so that he is considered a "journalistic figure" of the period. ${ }^{44}$ His political writings reflected his activism as a supporter of the Whig cause and of Fox; and he has been described as being "of some help to Fox and his friends with their newspaper problems", that is, the attacks on Fox's lifestyle and views by the London press. ${ }^{45}$ O'Bryen continued to fire off missives to the press throughout his life. In 1820 he admitted being "in the course of my life, and still an occasional correspondent of several papers ... like thousands of others", but denied ever having had any ownership, managerial employment or other concerns in any newspaper. ${ }^{46}$

Then, of course, there are also numerous but scattered pieces of correspondence with and from O'Bryen. There are several references in published sources to archival materials ${ }^{47}$ containing correspondence between O'Bryen and Fox and also

43 When the King's “madness" returned in 1810, O'Bryen's pamphlet was reproduced with a new preface under the title The Regency Question, being a Re-publication of Papers written during His Majesty's Illness in 1788 ... . Ultimately, the Prince of Wales became regent only in 1811 and succeeded his father as George IV only on his death. On George III (1738-1820), see, generally, Christopher Hibbert George III. A Personal History (London, 1998).

44 See Richmond P Bond's review of Lucyle Werkmeister The London Daily Press 1772-1792 (Lincoln, Neb, 1963) in (1964) $63 \mathrm{~J}$ of English and Germanic Philology 526-527.

45 Loren Reid "Charles Fox and the London Press" (1961) 47 Quarterly J of Speech 390-397 at $391 \mathrm{n} 4$. O'Bryen was, eg, a "long time associate" of Henry Bate (1745-1824), who was "the most prominent and the most notorious newspaper editor in London during the 1780s" and who "published an unprecedented volume of scurrilous material in his paper", the Morning Herald, a newspaper militantly pro-Foxite. Bate's "constant involvement in fist fights and duels won him the nickname the Fighting Parson" and in Sep 1780 O'Bryen was his second in his duel with one of the owners of the paper. See, further, Bonnie Ferrero "The Morning Herald and its first three editors" (2005) 11 Media History 165-175 at 168; Hannah Barker sv "Dudley, Sir Henry Bate" in Oxford Dictionary of National Biography (2004, online ed 2007, accessed 19 May 2014).

$46 \quad 12$ Oct 1820 The Times at 3.

47 For instance, British Museum Add MSS 46565, 47566, and 47591 (see, eg, Richard E Willis "Fox, Grenville, and the recovery of opposition, 1801-1804" (1972) 11 J of British Studies 24-43 passim). 
other Whig supporters and acquaintances such as Sheridan, ${ }^{48}$ Burke, ${ }^{49}$ Lord Grey, ${ }^{50}$ Thomas Erskine, ${ }^{51}$ and the Prince of Wales. O'Bryen had become an important if not completely indispensable cog in the Whig party machinery. ${ }^{52}$ Working for the party under the supervision of William Adam, a political manager, O'Bryen, "if not in receipt of regular payments from [Whig] party funds in this period, was a close associate of Fox and was employed by the party for various purposes with great regularity", and continued to act for the party into the next century. His services brought him financial reward, of which he appeared to be in constant and dire need; he had apparently been given "an annuity" out of party funds while it was in office in $1782,{ }^{53}$ and in the first decade of the nineteenth century, the party undertook a subscription to relieve O'Bryen of his debts.

It is not surprising, then, that Denis O'Bryen is today described as being closely connected to Fox and the Whigs: he is variously referred to as " $[\mathrm{t}]$ he Foxite Whig pamphleteer", ${ }^{54}$ Fox's "secretary", 55 his political and election "agent at

48 Richard Brinsley Butler Sheridan (1751-1816) was an Irish playwright (he is best known for The Rivals (1775) and School for Scandal (1777) and as the creator of Mrs Malaprop), poet, theatre owner and manager, and politician. An admirer and later friend of Fox, he was a Whig member of Parliament for many years (1780-1812), under-secretary of state (1782-1783) and with Fox the secretary (see n 42) and treasurer of the Navy (1806-1807) in Lord Grenville's government. O'Bryen has been called an "[i]ntimate" of Sheridan's (Manogue (n 39) at 285). In 1806 , O'Bryen secured a $£ 400$ loan for Sheridan and in 1816, when Sheridan was in ill health and as usual in financial trouble, "a friend", Denis O'Bryen, wrote a letter to the Morning Post calling on Sheridan's former fellow politicians to come to his aid (see A Norman Jeffares $s v$ "Sheridan, Richard Brinsley" in Oxford Dictionary of National Biography (2004, online ed 2008, accessed 9 Apr 2014). In yet another quirk of history, and not unrelated to the story of O'Bryen himself, Sheridan managed to arrange a post for his ailing son Thomas (1775-1817) at the Cape of Good Hope. Thomas arrived in Jun 1815 and was appointed colonial paymaster and assistant deputy adjutant general, which offices he held until his death (see Philip (n 9) at 378). In 1832, his widow received a pension of $\$ 300$ from colonial funds (R Montgomery Martin History of the British Colonies Vol IV: Possessions in Africa and Australasia (London, 1835) at 130).

49 Edmund Burke (1729-1797) was an Irish-born author and politician. He represented the Whigs in Parliament 1765-1794. As a supporter of the American revolutionary cause and, later, an opponent of the French Revolution, he became a leading figure in the conservative faction of the Whig party (the "Old Whigs"), in opposition to the "New Whigs" led by Fox. In Feb 1790, O'Bryen and others arranged a meeting to mend the breach between Burke and the Fox-supporting Sheridan, the outcome of which was an agreement not to discuss the subject of the French Revolution in the House of Commons. On Burke, see Paul Langford sv "Burke, Edmund" in Oxford Dictionary of National Biography (2004, online ed 2012, accessed 16 Jul 2014).

50 About whom more in due course (see $\mathrm{n} 81$ below).

51 About whom likewise more shortly (see $\mathrm{n} 60$ below).

52 For what follows, see Donald E Ginter "The financing of the Whig party organization, 17831793" (1966) 71 American History Review 421-440 at 431.

53 Maybe this was the "secret pension" referred to in the text to $n 39$ above.

54 Manogue (n 39) at 265.

55 Idem at 285. 
Westminster", ${ }^{56}$ and a "zealous political partisan" of Fox with whom he was "on terms of great intimacy". ${ }^{57}$ In short, O'Bryen was more than "a bit player in Whiggish politics"; he was "an important figure in the Whig world over a period of decades". 58

However, in attaining this position of political importance, O'Bryen did more than merely put pen to paper.

In November 1782, for instance, he fought a duel ${ }^{59}$ in Brighton with the lawyer, Thomas Erskine, already an established figure in legal and Whig political circles. ${ }^{60}$ Their disagreement and its eventual favourable and magnanimous resolution appear to have been carefully calculated by O'Bryen with a view to gaining maximum political advancement in a cliquish Whig world. ${ }^{61}$

In June 1786, O'Bryen was involved as a witness for Fox in a civil trial in the Court of Common Pleas. ${ }^{62}$ Fox had demanded compliance from Corbet, the high bailiff of Westminster, with a writ issued by the Court of Exchequer to return himself and another as elected members of Parliament for the City of Westminster, but compliance was delayed. Fox won the case and received the $£ 2000$ damages he had claimed for losses caused and expenses incurred. ${ }^{63}$

56 LG Mitchell "Foxite politics and the Great Reform Bill" (1993) 108 English Historical Review 338-364 at 362 .

57 Cooper (n 36). According to O'Shaughnessy (n 3) it appears from their correspondence that "Fox lent on O'Bryen for judicious decision-making grounded in their friendship" and that O'Bryen could not only offer "judgment" to accompany Fox's flamboyant personality, but also protect Fox from the frequent personal attacks upon him by the press and political opponents. Correspondence between the two indicates a strong personal friendship going beyond a mere political alliance and involving an exchange of gifts and social invitations to the Fox home.

58 O'Shaughnessy (n 3).

59 His second known involvement in a duel (see $\mathrm{n} 45$ above).

60 Thomas Erskine (1750-1823), who, being the "son of a nobleman ... was entitled to a degree without examination", soon became a prominent junior lawyer in the 1770 s. He was a leading member and later leader of the Bar in the 1780s, an associate and supporter of Fox, and gained further prominence defending radical politicians and activists in the 1790s ( $c f$, eg, his involvement in the O'Connor treason trial discussed at $\mathrm{n} 67$ below). He was Lord Chancellor from Feb 1806 to Apr 1807. On Erskine, see David Lemmings $s v$ "Erskine, Thomas, First Baron Erskine" in Oxford Dictionary of National Biography (2004, online ed 2008, accessed 19 May 2014).

61 See O'Shaughnessy (n 3) for this. With O'Bryen's permission, Erskine fired the first shot but missed. O'Bryen then simply fired his pistol into the air. Erskine, relieved to escape unharmed (he had in fact had a will drawn up beforehand in anticipation of an unfavourable outcome), called O'Bryen a man of honour and likewise fired his second pistol into the air.

62 Fox $v$ Corbet, reported in 22 Jun 1786 The Times at 3.

63 Fox, having lost to Lord Samuel Hood but having beaten Sir Cecil Wray and in the process having gained sufficient seats to become a member of Parliament, was barred from taking his seat until after an official scrutiny. (At the time, it was possible for there to be more than one member per constituency, eg, at Westminster there were two members, Fox with Hood in 1784-1788 and 17901797 and with Wray in 1782-1784.) Fox's barring was a delaying tactic by the Pitt government. After several months, the House of Commons intervened and voted to allow Fox his seat. Fox nevertheless sought recompense by bringing the civil action (see Foreman (n 41) at 156). 
Many years later, in 1798, O'Bryen was heavily involved in two trials ${ }^{64}$ that showed not only his Whig connections but also that he remained "a proud and patriotic Irishman with a fervent interest in promoting his country". ${ }^{65}$

The first was the political trial ${ }^{66}$ of Arthur O'Connor ${ }^{67}$ and four other Irishmen for high treason. ${ }^{68}$ They appeared before the Court held under Special Commission at Maidstone, on 21 and 22 May 1798. At the time, United Irishmen were hoping to receive the help of France in a planned rebellion that ultimately proved unsuccessful. The indictment against the accused included three separate acts of treason: "compassing" the King's death; aiding and comforting the King's enemies; and persuading and engaging the French government and subjects to invade Britain with force. After two marathon sessions, ${ }^{69}$ and having heard the evidence for the prisoners from a galaxy of liberal political luminaries - Fox, Sheridan, Erskine, Lord John Russell and Lord Thanet - the jury took just forty minutes to find one of the accused

64 O'Bryen, it seems, may have been personally quite familiar with litigation and may well have been the "Dennis O'Bryen" involved in the following legal proceedings (this information comes from the website of the National Archives (NA), Kew, available at http://www.nationalarchives. gov.uk (accessed 10 Apr 2014): (1) 16-19 Sep 1778, Henry William Smallwood, of Staple Inn, and Eleanor his wife (nee Perkins) releases [sic] Dennis O'Bryen, surgeon, of Norfolk Street, Strand: Robert Carter of Market Court, Covent Garden, witnesses the release (MJ/SP/1778/09/080: Middlesex Sessions of the Peace, Session Papers, Sep Gen Sessions, in the London Metropolitan Archives); (2) 1798, Dennis O'Bryen \& Ano v Mary Woodifield \& James Speller (C 12/1426/10 in the NA); and (3) 1800: Dennis O'Bryen pltf v Francis Dashwood SMP dfdt (C 13/480/4 in the NA).

65 O'Shaughnessy (n 3). O'Bryen's name is included in Samuel Simms "A select bibliography of the United Irishmen, 1791-8” (1938) 1 Irish Historical Studies 158-180 at 166.

66 One of many during the 1790s: see FK Prochaska "English state trials in the 1790s: A case study" (1973) 13 J of British Studies 63-82. They often concerned charges of seditious libel and were viewed by the Whigs as attacks on freedom of speech and the press (idem at $71 \mathrm{n} 30$, referring to a letter from Fox to O'Bryen).

67 Arthur O'Connor (1763-1852) was an Irish nationalist and from 1796 a leading member of the United Irishmen, a group planning their own revolution and seeking French aid for this. With Lord Edward Fitzgerald, he acted as an emissary and travelled to France in mid-1796. The result was an abortive landing of the French fleet at Bantry Bay. After being jailed for most of 1797, O'Connor was back in England in Feb 1798, en route to seek further French aid in support of an Irish revolution, but he was arrested with others on charges of treason. O'Connor had a longlasting friendship with Sheridan and political connections among the Foxites, including with Fox himself. On O'Connor, see James Livesey sv 'O'Connor [formerly Conner; later CondorcetO'Connor], Arthur" in Oxford Dictionary of National Biography (2004, online ed 2013, accessed 29 May 2014).

68 See $R$ v O'Coigly, O'Connor, Binns, Allen \& Leary (1798) 26 State Trials 1191, (1798) 27 State Trials 1; also "Trial for High Treason ... Maidstone, Kent in 1798", available at http://freepages. genealogy.rootsweb.anchestry.com (accessed 29 May 2014). On how the trial was reported in the press, see CC Barfoot "Reporting a treason trial in 1798" (1994) 2 Studies in Newspaper and Periodical History 45-58.

69 Proceedings lasted sixteen hours on the first day (from 7 am to $12 \mathrm{pm}$ ) and more than seventeen hours on the second day (from 8 am to 2 am). 
guilty ${ }^{70}$ and the others, including O'Connor, not guilty. Although he attended the trial, it does not appear that O'Bryen testified.

O'Connor was immediately rearrested and held in custody for more than five years on other charges. His attempt to leave the Court on being found not guilty, viewed by the authorities as an attempt to escape being rearrested, was accompanied by a violent disturbance in the courtroom. O'Bryen was heavily implicated in starting this fracas and consequently charged, together with others, with inciting a riot and with a range of other misdemeanours.

$R v$ Earl of Thanet, Ferguson, Browne, O'Brien \& Thompson ${ }^{71}$ was tried in the King's Bench on 25 April 1799 and was a high-profile affair. It involved several leading legal lights, ${ }^{72}$ and was described, rather hyperbolically, by the attorneygeneral as concerning the commission of "an offence which appears to me to be one of the most heinous, the consideration of which has been offered, in the history of our law, to the decision of a jury".

There were a number of witnesses for the accused, including Sheridan. ${ }^{73}$ With regard to O'Bryen, he stated that he knew him intimately and confirmed that he was "a strong man" who could, had he wanted to, have assisted O'Connor in escaping, but was instead arguing with the officials present. ${ }^{74}$ From the evidence presented,${ }^{75}$ so

70 In the absence of mitigating circumstances, James O'Coigley (or Quigley), received the "usual sentence" for high treason and was executed near Maidstone on 7 Jun. The usual sentence, according to Barfoot (n 68) at 54, was for the prisoner "to be hanged, but not until he be dead; to be taken down while still alive, and then to have his heart and bowels taken out and burnt before his face; his head to be severed from his body; and his body to be divided into four quarters".

71 (1799) 27 State Trials 821 (KB). The accused were the Rt Hon Sackville Tufton, the ninth Earl of Thanet; Robert Ferguson, Esq, a barrister; Gunter Browne, Esq; Dennis O’Brien, Esq; and Thomas Thompson.

72 Counsel for the Crown included attorney-general Sir John Scott (afterwards Lord Chancellor Eldon), Mr Law (afterwards Lord Ellenborough and Lord Chief Justice of the King's Bench), $\mathrm{Mr}$ Garrow and Mr Wood (both afterwards barons of the Exchequer), and Mr Abbott (afterwards Lord Chief Justice of the King's Bench). Counsel for the defendants included Thomas Erskine (afterwards Lord Chancellor Erskine: see n 60 above), Mr Gibbs (afterwards Lord Chief Justice of the Court of Common Pleas), and Mr Best (afterwards a judge on the King's Bench).

73 Although some sources suggest that Sheridan may have organised the riot, others assert that it was his intervention (asking the judges why, if O'Connor had been acquitted, he was still being held) that restored order in the courtroom, an action that resulted in Sheridan's not being prosecuted with the others.

74 See at 924 of the report.

$75 \mathrm{Eg}$, there was no evidence for the prosecution of any contact between O'Bryen and Thanet in court during the trial (idem at 837, 850-851), although he was present in the witness box, standing by Sheridan, Fox and others (idem at 862); and although O'Connor had on one occasion leaned on O'Bryen over the bar (idem at 839). He had also been present in court at the time of O'Connor's acquittal and had conversed with him (idem at 859), and had then enquired from the officials whether there was a (new) warrant against O'Connor after his acquittal (idem at 851); however, O'Bryen had left the courtroom just before O'Connor tried to make his alleged escape (idem at $865)$. 
the defence argued, it appeared that although present, O'Bryen could not be proved to have been actively involved in any riotous acts. ${ }^{76}$

Although two of the accused were found guilty and two others were acquitted, ${ }^{77}$ O’Bryen was found not guilty.

The end of his direct and active involvement with Fox and the Whigs was, however, not many years away. When the Pitt government resigned in February 1801, Fox “returned" to active politics. On Pitts' death in January 1806, he entered into an understanding with the Grenville faction of the Whig party, which took office as the "ministry of all talents" in January 1806, with Fox again being appointed as foreign secretary.

However, by then Fox was already ill and he died in September 1806. On the death of his friend and patron, O'Bryen wrote a letter to The Times, modestly putting himself forward by raising the prospect of his being asked to stand for election to the vacant seat in Westminster. He observed that "[a] fit successor to him, who is no more, one cannot expect; for his equal is not in the creation", but nevertheless claimed to be worthy of consideration as such "on the score of the connection that for twenty-five years bound me to the cause and service of that illustrious person". ${ }^{78}$

Nothing came of this. The Whigs were in power for only a few more months but by then O'Bryen had already secured another advancement from his Whig connections. ${ }^{79}$

On 30 August 1806, The Times ${ }^{80}$ announced that Lord Howick ${ }^{81}$ had appointed Denis O'Bryen, Esq, "to the office of Marshal of the Vice Admiralty Court of the

76 More specifically there was no evidence from his conduct in court of any evil design, much less of a concerted one with the other defendants. He was not implicated at all in the riot, nor concerned in any violence or disturbance whatsoever. In short, the defence suggested, as far as O'Bryen was concerned, "there is literally no proof to be answered" (idem at 883 and see, also, at 905).

77 Thanet was fined £1 000 and sentenced to one year's imprisonment in the Tower of London; Ferguson was fined $£ 100$ and imprisoned for one year, while Browne and Thompson were acquitted with the prosecution's consent. The conviction must be seen in the light of the evidence showing the riotous conduct of Thanet and Ferguson and the explanation by Lord Kenyon in his summing up for the jury. He observed that there was no doubt that O'Connor was not entitled to be discharged, because when a verdict of acquittal is entered, the judge may order the party in question to be detained and compel him to answer other charges that may have been brought against him (idem at 940).

$78 \quad 17$ Sep 1806 The Times at 2.

79 He had already received an annuity (1782), a pension (1783) and debt relief (early in the nineteenth century) from the Whigs for services rendered (see nn 39 and 53 above).

80 At 2.

81 Charles Grey, the second Earl Grey (1764-1845), known as Viscount Howick from 1806-1807 when he was First Lord of the Admiralty, and first elected to Parliament in 1786, became a member of Fox's Whig party (he supported Fox in the regency crisis 1788-1789), and later one of its leaders in opposition to Pitt. Grey entered the cabinet as the First Lord of the Admiralty in Feb 1806 despite his inexperience in naval affairs. It was in that capacity that he appointed O'Bryen as Admiralty marshal. On Fox's death in Sep 1806, he succeeded him as foreign secretary and 
Cape of Good Hope". The report continued that when his lordship had communicated his appointment to O'Bryen, he enhanced its value by the assurance that O'Bryen owed it to "the particular request of Mr Fox, as a return for his long, zealous, and faithful attachment". The office was said, the report continued, to be of considerable emolument "and can be executed by Deputy". By the time O'Bryen gained entry into the Dictionary of National Biography, his appointment in 1806 "to the patent office of marshal of the Admiralty [sic] at the Cape of Good Hope, worth, it was said $£ 4$ 000 per annum", was described as a "lucrative sinecure". 82

Clearly O'Bryen's appointment as marshal of the Vice-Admiralty Court at the Cape of Good Hope was not an ordinary appointment involving his translocation to the settlement to take up his duties there. Some explanation of sinecure appointments and patent offices is therefore required.

\section{$4 \quad$ Patent offices and colonial appointments}

Until well into the nineteenth century, a "complex and unsystematic" system of patronage existed in respect of various public offices and positions in the United Kingdom. ${ }^{83}$

The system included not only the bestowal of honours (knighthoods, peerages, court appointments and nominations to various chivalrous orders), but also the nomination to salaried offices - so-called salaried patronage. Nominations were usually for life and were not revocable, at least not legally. They were for important posts involving the performance of serious and demanding duties, as well as the most glaring of sinecures. ${ }^{84}$ Public servants were so appointed, often with no or inadequate qualification for their posts; they received little if any official remuneration or salary and derived their income from fees and gratuities levied on the public for the services

leader of the Foxite faction of the Whigs and hence also of the House of Commons, holding those positions until Mar 1807 when the Whig government resigned. During the "talents ministry", Fox had secured an earldom for Grey's father, Genl Sir Charles Grey (1729-1807). In Apr 1806 Grey himself adopted the "courtesy title Viscount Howick", which he used until his father died in Nov 1807, when he inherited the earldom as the second Earl Grey and entered the House of Lords. There he remained in opposition until his appointment as Whig Prime Minister in Nov 1830 after the resignation of the Duke of Wellington's government, a position he held until Jul 1834. He is the Earl Grey after whom the bergamot-oil flavoured tea blend was named. On Earl Grey, see, further, EA Smith sv "Grey, Charles, second Earl Grey" in Oxford Dictionary of National Biography (2004, online ed 2009, accessed 10 Apr 2014). On the involvement of the Grey clan in affairs at the Cape of Good Hope, see, further, $n 175$ below.

82 Cooper (n 36).

83 JM Bourne Patronage and Society in Nineteenth Century England (London, 1986) at 13. Much of what follows in the following five paragraphs is drawn from this source.

84 The term "sinecure" is derived from "sine" (without) and "cura" (care or duty) and refers to an appointment to a salaried office that involves little or no responsibility or active service or labour on the part of the appointee. Originally of ecclesiastical origin (a benefice without the obligation of caring for souls), it was later also applied to secular offices. 
they rendered in the performance of their duties. ${ }^{85}$ For monarchs and governments the system was a powerful means of distributing patronage or rewarding or securing political support.

There were, broadly, two methods of appointment: by Letters Patent under the Great Seal, or by Warrant under the King's Sign Manual. ${ }^{86}$ An appointment to an office by the former method was referred to as an appointment to a patent office.

As from the end of the eighteenth century, hesitant and ineffectual steps were taken to suppress sinecures, reform the system of patronage, and transform the "civil service" in an attempt to eradicate maladministration and inefficiency. ${ }^{87}$ Public pressure for reform was kept up by a series of Black Books and Red Books, the product of the radical press, authored anonymously by "A Commoner". These books were highly critical of complex, secretive and wasteful financial management and state expenditure and included a detailed list of "Pensions, Sinecures, Places, Compensation and Emoluments" in the United Kingdom and the colonies, as well as a financial review of the income and expenditure of the civil list, Britain's finances and debt, and Crown revenues.

The first pertinent step towards reform was the appointment of a House of Commons Select Committee on Sinecures in 1810, about which more shortly. It found that there were 242 sinecures in the Kingdom and the colonies. However, general legislative reform failed and a series of legislative measures dealt in piecemeal fashion with the issue. Nevertheless, by 1834 there had been steady growth in the numbers employed by the government in its executive department or "civil" service, and there were only 108 sinecures left, most of which were already destined for extinction in due course. By 1850, "[s]inecures had lapsed into irrelevance". ${ }^{88}$

Crown and government patronage, even if shorn of sinecures, its most objectionable feature, which continued to be the medium through which public services were recruited, slowly faded from public debate. By the mid-nineteenth century, increased regulation and re-organisation of the public service in the cause of efficiency came to restrain the free exercise of patronage. The result was the

85 Bourne (n 83) at 13-14

86 This is explained by the guide entitled "Royal grants in Letters Patent and charters from 1199", available at http://www.nationalarchives.gov.uk/records/research-guides (accessed 27 Jun 2014) as well as by the several Parliamentary Papers referred to below. Letters Patent is a type of legal instrument in the form of a published, written order or proclamation by the Crown or government granting, eg, an office, right, property, monopoly, or title, to a private individual or a public body. The term (litterae patentes) refers to "open" or "accessible" letters (in the sense of writing or the letters of a word, and not in the sense of an epistle, hence "letters" not "letter' patent), as opposed to sealed and private letters (litterae clausae); letters readable by everyone in that the seal was attached pendent from the document and not "sealing" or "closing" it. Collections of royal Letters Patent were taken up ("enrolled": sheets of parchment were sewn together to form a continuous roll) in Patent Rolls.

87 Bourne (n 83) at 20-24.

88 Idem at 167. 
appointment of those suitably qualified for office and hence "efficient" patronage. ${ }^{89}$ By 1870 the "onslaught of merit" had seen the arrival of "open competitive entry". 90 Included in the system of patronage and the list of sinecures produced in attaining these reforms, were various judicial offices. ${ }^{91}$ They were likewise reformed in the first half of the nineteenth century, ${ }^{92}$ as part of a broader reform of the judicial system generally.

Briefly, as far as the superior common-law courts were concerned ${ }^{93}$ numerous inferior offices in these courts were either absolute sinecures in that the appointee himself did no work but earned an income from fees generated by a deputy to whom his duties were delegated, or partial sinecures. Reforms were aimed at the elimination of judicial offices that were sinecures, and the introduction of a greater reliance on salary-based compensation as well as a regulation of the collection of, and a cap on, fees by the holders of such offices. These measures were introduced piecemeal, for instance by the Common Law Courts (England) Act, 1830; ${ }^{94}$ the Court of Exchequer

89 Idem at 31; there was no advantage "in appointing an idle, incompetent, epileptic, aristocratic bastard to a post of real responsibility" (idem at 167).

90 CI Hamilton "John Wilson Croker: Patronage and clientage at the Admiralty, 1809-1857" (2000) 43 The Historical $J 49-77$ at 63.

91 For a description of how - slowly and "extremely burdensome and wearing to both protégé and patron", and with little if any political significance - the patronage system operated at the Admiralty, see ibid.

92 See James E Pfander "The chief of the court: Article II and the appointment of inferior judicial officers" (2012) Faculty Working Papers, Northwestern University School of Law, available at http://scholarlycommons.law.northwestern.edu/facultyworkingpapers/224 (accessed 20 Jun 2014) at 13-18 for a succinct summary of the background to common-law courts. The following exposition is heavily reliant on this source. For the reform of civilian courts, see, eg, Wiswall (n 31) at, eg, 36, 41-42, 57-59 and 80; Anthony Hugh Manchester "The reform of the ecclesiastical courts" (1966) 10 Am J of Legal History 51-75; and RB Outhwaite The Rise and Fall of the English Ecclesiastical Courts, 1500-1600 (Cambridge, 2006) at 104 et seq.

93 These were the Court of the King's Bench, the Court of Common Pleas, and the Court of the Exchequer. (Other courts included the Court of Chancery and various civil-law courts such as the various ecclesiastical courts and the Admiralty Court.) Officers of these courts received (1) salaries, paid by Parliament; (2) an income derived from fees (paid by litigants as part of the cost of litigation and irrespective of the outcome of litigation; by contrast, Admiralty judges' judicial fees depended on the outcome, and earned them a substantial fee when condemning a vessel as prize but less otherwise!); and (3) an income from the appointment of individuals to offices within the judge's "gift" or patronage, which grew with the length of the judge's service as offices became vacant and required re-appointment. Unless he decided to keep an office for himself as an additional income, a judge could either sell the relevant office(s) outright (bargaining with the purchaser in the expectation that the appointment to a sinecure would provide an annuity for the individual appointed), or he could appoint a member of his own immediate or extended family or his circle of friends to the post. It is estimated that the relevant chief justices and the Chancellor in particular earned quite considerably more from fees and patronage than from their direct salaries. See, further, Pfander (n 92) at 13-18.

9411 Geo IV \& 1 Will IV c 58. It regulated the receipt and future appropriation of fees and emoluments receivable by officers of the superior courts of common law. The object of the Act, 
(England) Act, 1832; ${ }^{95}$ the Lord Chancellor's Pension Act, 1832; ${ }^{96}$ and the Superior Courts (Officers) Act, 1837. ${ }^{97}$

For present purposes, though, the focus is on the system of patronage in colonial appointments, including judicial patent offices. ${ }^{98}$

At the end of the eighteenth century, most senior colonial officials received no stipends or very small ones and were expected to live on fees levied on the public they served. The fee-earning colonial office was regarded as a form of property, which could be conferred by the Crown or the government on a subject or supporter.

according to the decision in Clarke \& Another $v$ Richards (1835) 1 Y \& C Ex 351, 160 ER 143, was to provide the means of paying the officers of the various courts of justice by salaries instead of fees. See, also, the explanatory and amending Officers of Common Law Courts Act, 1831 (1 \& 2 Will IV c 35).

952 \& 3 Will IV c 110, which sought to better regulate the duties performed by the officers on the plea or common-law side of the Court of Exchequer. The measure was said in the decision in Clarke \& Another $v$ Richards (1835) 1 Y \& C Ex 351, 160 ER 143 to be aimed at distributing the duties of the officers of the Court of Exchequer and giving them appropriate names.

$962 \& 3$ Will IV c 111. Despite its (subsequently conferred) title, the Act also abolished certain sinecure offices (they are listed in s 1 and include offices of the keeper or clerk of his Majesty's Hanaper, the patentee of the Subpoena Office, the registrar of affidavits and ten other equally arcane ones) connected with the Court of Chancery. In terms of s 2, though, the Act was not to be construed to determine (abolish) any of these offices at the time held in possession or reversion by any person appointed to them before Jun 1832 until the death or resignation of that person. It was followed by the Lord Chancellor's Offices Act, 1833 (3 \& 4 Will IV c 84) which provided for the appointment by the Crown of "competent" persons to perform the duties of certain of those abolished offices connected with the Court of Chancery as and when they became vacant, and also for current and future office-holders to be paid by salary in full satisfaction of their services and expenses incident in its performance.

977 Will IV \& 1 Vict c 30 . The preamble observes that the duties of many officers in these courts have wholly or in part ceased, or are executed by deputy, and that the offices have, because of changes in the law, become useless and inapplicable to present practices and proceedings, but that the fees in respect of those offices continue to be payable by litigants. Further, it noted that the continuance of sinecures and useless offices tends to impair the effective administration of justice and to impose unnecessary burdens and costs on the public and litigants in those courts. The Act therefore abolished certain offices in the superior courts of common law (they are listed in Sched A to the Act and the more than forty-five offices mentioned there include, in the Court of Queen's Bench, eg, those of the clerk of rules, the clerk of papers, the signer of writs, the clerk of declarations, the clerk of errors, the clerk of the outer treasury, and "the bagbearer to the Custos Breviorum"), and in the Court of Common Pleas as well as in the Court of the Exchequer, the offices of prothonotary (on the latter, see generally RW Bentham \& JM Bennett "The office of prothonotary. Its historical development in England and in New South Wales" (1959) 3 Sydney LR 47-70). The Act made provision for a more effective and uniform appointment, at fixed salaries, of masters or principal officers of those courts to perform the duties and exercise the powers and authority connected to the abolished offices.

98 See, in particular, JH Parry "The patent offices in the British West Indies" (1954) 69 English Historical Review 200-225 which provides valuable background information on the patent office system as it operated in the colonial context. On patronage in the East India Company, see Bourne (n 83) at 180-185. 
The monarch or government ministers regularly used their powers of patronage, at home and abroad, to gratify friends, clients and supporters. ${ }^{99}$

Appointment was without reference to the relevant colonial authorities - either the Colonial Office or the governor of the colony in question - by Letters Patent under the Great Seal. Further, the appointment could not be cancelled except for the gravest cause and by due process of law. In short, a colonial patent office appointment involved no fixed and secure salary but also no ready dismissal.

Nor could the Crown or government always ensure proper or even personal performance, especially in distant colonies. Appointees often arranged for the performance of any duties involved in the office by deputies, so that fee-earning offices in colonies became in effect life sinecures.

Colonial offices were often granted by Letters Patent ${ }^{100}$ to men who had obligations or duties in England, had no intention of leaving England and residing abroad, and who performed their colonial duties by deputy. In 1821 the Red Book $k^{101}$ observed sarcastically that "[m]any Honourable and Right Honourable Gentlemen fill the offices of clerks, harbour-masters, naval officers, tide-waiters, collectors, comptrollers, surveyors, \&c. in places and countries which they have never seen except on the map, if they have seen them even there". Such deputies either retained a share of the fees of the office and remitted the remainder to their principal in England, or otherwise paid their principals a fixed annual lump sum, giving security for it and for the proper execution of the office.

Offices patented in the colonies covered a wide spectrum, several of them being judicial offices. ${ }^{102}$ The only senior officials who remained, as a class, outside the system, were colonial governors and judges, who were appointed by Commissions under the Great Seal, received stipends and were not allowed to serve by deputy.

Clearly the system of patent offices had serious defects. ${ }^{103}$ Neither the authorities in London nor the colonial governor and his administration could effectively control

99 Bourne (n 83) at 28 points out that colonial patronage and colonial appointments "were an important addition to the arsenal of ministerial patronage".

100 The procedure for appointing officials by Letters Patent was slow and complicated and involved the patentee in considerable expense, which he sought to recover, directly or through his deputy, from the collection of fees (see Parry (n 98) at 201).

101 The Extraordinary Red Book: An Account of all Places, Pensions, Sinecures, Grants, \&c ... to February 18214 ed (London, 1821) at vii-viii.

102 For example, as appears from Parry (n 98) passim, in the West Indies the offices of colonial secretary, provost-marshal, clerk of the naval office, and chief clerk and registrar of the various courts were often patent offices.

103 For an informative decision on how the patent system operated, which also illustrated the many abuses that occurred in connection with it, see $R v$ Vaughan (1769) 4 Burr 2494, 98 ER 308. It concerned an attempt to bribe a Privy Councilor (the Duke of Grafton, First Lord of the Treasury at the time) to procure a patent for the reversion of the office of the clerk of the Supreme Court of Jamaica. The Court referred to the office as one that "had been sold, devised, leased, and very badly executed by deputy" (at 2496, 309) and one that "is granted by letters patent under the 
the appointment of patent officers or the manner in which they, or their deputies, executed their duties, let alone speedily remove the patentees or their deputies from their offices when that was desirable. Not only were incompetent persons appointed to the offices; they, in turn, often appointed incompetent and corrupt deputies to perform their duties locally. Furthermore, patentees themselves often had little control over or indeed any contact with their deputies. Business between them was increasingly handled by brokers, who charged a commission, for instance for obtaining the services of a deputy who was often merely the highest bidder for the appointment. Finally, patentees were usually well able to defend their privileges and profits against any complaints. They were often supported and defended by the relevant minister or governmental institution that had supported their appointment and had a vested interest in defeating colonial attempts to have patentees removed or controlled. Thus, the Lords of the Admiralty, who appointed Vice-Admiralty judges and court officials in the colonies, and the Commissioners of Customs who appointed customs officers there, could be relied on to support their appointees against gubernatorial censure. ${ }^{104}$

However, growing opposition in the course of the eighteenth century increasingly focused on the abuses inherent in the system such as the appointment of non-resident, absent patentee officers and the tendency of patent officers and their deputies to demand excessive fees for their services.

The first reaction to complaints and the first steps towards reform came in the form of the Colonial Leave of Absence Act, 1782. ${ }^{105}$ It provided that every holder of a colonial office conferred by royal Letters Patent had to reside in the colony and perform his duties in person, unless he received leave of absence, which had to be granted by the governor of the colony. ${ }^{106}$ However, the Act applied only

Great Seal of England" and therefore governed by the common law (at 2500, 311). In rejecting the defence's contention that "[ $\mathrm{t}$ ]he solicitation to take money for an office in the colonies, is no offence", and finding for the Crown that such an attempt was a misdemeanour at common law and punishable as such, Lord Mansfield thought (ibid) that even "[i]f these transactions are believed to be frequent, it is time to put a stop to them. A minister trusted by the King to recommend fit persons to offices would betray that trust, and disappoint that confidence, if he should secretly take a bribe for that recommendation". See, also, eg, Blankard v Galdy (1793) 4 Mod 215 and 222, 87 ER 356 and 359; (1794) Holt KB 341, 90 ER 1089; (1795) 2 Salk 411, 91 ER 356, concerning the purchase of the office of provost-marshal in Jamaica and the inapplicability of English statutes prohibiting such an act.

104 Parry (n 98) at 205.

10522 Geo III c 75. It is also known as Lord Shelburne's Act; he was secretary of state at the time (see n 38 above).

106 Section 1 prevented the granting "in future" of any "Patent Office" to be exercised in any Crown colony for any longer term than during such time as the grantee or appointee discharged the duty concerned in person and behaved well in it. It referred to the practice of "granting offices in colonies to persons residing and intending to reside in Britain that had long been complained of in the colonies as causing inconveniences from a neglect of duty". In terms of s 2 , if the patentee was wilfully absent without leave or neglected the duties of his office, the governor was permitted 
prospectively ${ }^{107}$ and excepted patents already issued. It was resented by those who could benefit by the system; loopholes were soon found ${ }^{108}$ and the Act was rendered practically ineffective.

Consequently, the colonial patent office system expanded greatly during the last decades of the eighteenth and first decade of the nineteenth century. It had become an important political tool, frequently used to thank supporters and loyal party members. It was therefore, not surprisingly, increasingly the system's financial implications and its burden on public funds, rather than the abuses linked to it or its administrative inefficiency, which became the focus of those intent on reforming it.

In 1821, the Red Book ${ }^{109}$ estimated that the value of sinecures in the colonies amounted to nearly $\$ 100000$ per annum, "exclusive of those in the Cape of Good Hope, the Isle of France and Malta, which probably amount to as much more".

It was also on the grounds of financial concerns that the first effective attack on colonial patent offices was launched. ${ }^{110}$ The House of Commons Select Committee on Public Expenditure of the United Kingdom, appointed in 1806, produced a series of reports. Its third report of 1807 dealt with offices, places, sinecures and pensions, ${ }^{111}$ but only in the United Kingdom itself. ${ }^{12}$ This and the other reports caused the House of Commons to pass a series of resolutions calling for the abolition or reduction of such sinecures, although regard was to be had to existing interests. It set up a further select committee to consider what offices came within the purview of its resolutions.

This select committee, the Select Committee on Sinecure Offices, was again chiefly concerned with such offices in the United Kingdom itself. However, it

to remove him.

107 Section 4 made it clear that nothing in the Act "shall operate to the prejudice of any subsisting Grant of such Office or Offices".

108 For instance, appointments were made otherwise than by the specifically mentioned Letters Patent (eg, by the seal of the colony) so that they were not covered by the Act, or some high authority in London simply ordered the governor to grant the patentee leave of absence.

109 See (n 101) at vii.

110 The attack on sinecures in the political system, begun by Whigs in order to undermine the Tory King in the 1780s, eventually succeeded through the quite unobtrusive efforts of Tory governments in the nineteenth century (see Bourne (n 83) at 19-21 for considerable detail on the suppression of sinecures).

111 House of Commons Select Committee on Public Expenditure, Third Report (1807). This and all the other Parliamentary Papers referred to below are accessible online at http://0-parlipapers. chadwyck.co.uk.

112 It reported on various forms of patronage. It referred, at various places in its report to, eg, "an ambiguous and middle class, partaking in the nature of Pensions, in as much as no service is performed, but still ranking under the head of Offices, from the name of official business having been continued after the functions are become extinct and obsolete", that is, the appointed official was still remunerated although the functions and office had become obsolete. Such sinecures, it pointed out, were given as pensions ("to secure a honourable retreat"), or as an accompaniment to a peerage for the reward of personal service, and were difficult to distinguish from offices "such as are wholly or chiefly executed by Deputy". 
also heard evidence concerning patent offices in the colonies and had before it the voluminous returns of those offices sent by colonial governors in accordance with instructions issued in 1808. This Committee's first report, in $1810,{ }^{113}$ mentioned the colonies in passing and observed that despite the residential requirement of the Act of 1782 , the duties attached to many offices continued to be performed wholly by deputy. The patentees, it observed, "enjoy perfect sinecures". ${ }^{114}$

This Committee's second report, in $1811,{ }^{115}$ contained more detail on colonial patent offices, and on ${ }^{116}$ colonial officers appointed by the Admiralty, most of whose duties were performed by deputy. These included, in the various colonial Vice-Admiralty courts, seventeen registrars and fourteen marshals, ${ }_{117}^{17}$ most of whose duties were performed by deputies. The exact amount of their salaries or emoluments, which stemmed from fees and thus depended on the quantity of business transacted in the courts, ${ }^{118}$ was unknown but, the Committee pointed out, it was clearly more than enough to remunerate the persons performing the duties of the office. The committee's third report, in $1812,{ }^{119}$ contained further detail on the about 100 colonial patent offices, many of which, including some important ones, were served by deputies. ${ }^{120}$

Although the evidence before the Select Committee on Sinecure Offices afforded the first clear and detailed account of the way in which the patent office system operated, the Committee did not recommend any specific action on colonial patent offices. However, its reports did draw public attention to the many abuses of the system, in particular the repeated evasions of the Act of 1782.

In 1814, after earlier failed attempts in 1812 and 1813, legislation was eventually passed to address the issue. The Public Offices in Colonies Act, 1814 ${ }^{121}$ sought to address the loopholes in the Act of 1782. First, it required the occupants of all colonial offices, in whatever way granted, to reside in the colonies concerned. ${ }^{122}$ Next, it restricted and controlled the power of colonial governors to grant leave

113 House of Commons, Select Committee on Sinecure Offices, First Report (1810).

114 Since the income of these colonial offices arose altogether from fees payable in the colonies, the matter was not regarded as within the Committee's scope, which was aimed at reducing public expenditure in the United Kingdom, and it therefore did not make any recommendation to regulate or abolish them.

115 House of Commons, Second Report from the Select Committee on Sinecure Offices (1810-1811).

116 At 60.

117 See app 4 at 89-91.

118 I shall return to the information the report provided on the Cape Vice-Admiralty Court shortly (see n 132 below).

119 House of Commons, Third Report from the Select Committee on Sinecure Offices (1812).

120 The information on officers of Vice-Admiralty courts abroad contained in app 5 to the third report is essentially the same as that contained in app 4 to the second report.

12154 Geo III c 61.

122 Section 1 referred to offices "granted, either by Patent under the Great Seal, or by Commission under His majesty's Sign Manual, or by any other Commission, Warrant or Instrument". 
of absence by requiring governors, under threat of a financial penalty, to report on any leave granted to the secretary of state, who then had to confirm it. ${ }^{123}$ It also required annual reports to be laid before the House of Commons on persons holding offices in the colonies who had been appointed after the passing of the Act but who were not present there to carry out their duties. ${ }^{124}$ However, this Act too applied only prospectively and did not affect patent office holders appointed before it was passed. ${ }^{125}$

These strengthened measures ensured the proper enforcement, for the first time, of the requirement that colonial officials reside in the relevant colony and work for a living themselves. So successful was it that the patent office system almost disappeared from colonial appointments in the twenty years following its passage. No fresh patents of the old type were issued, and as existing patent holders died, the successors appointed had to carry out their duties in person. Nevertheless, appointees were still usually remunerated by fees rather than by fixed salaries.

In 1817, the Select Committee on Finance, ${ }^{126}$ investigating the United Kingdom's income and expenditure and ways in which the latter could be reduced without any detriment to the public interest, referred to sinecures and the costs incurred "by the continuance of Offices, either wholly useless, or the Salaries of which appear disproportionate to their actual duties". In respect of colonial offices, it observed that it possessed insufficient information to be able to present a full picture. ${ }^{127}$ Nevertheless, it thought that the general principles applicable in dealing with them appeared to be, first, enforcing the principal's residence and personal performance, and secondly, reducing remuneration to an amount that was fair and sufficient for the performance of services in the office.

In the years 1833,1834 , and 1835 , further select committees were appointed to report on progress in the abolition of sinecures, in both the United Kingdom and the colonies. The first report ${ }^{128}$ foresaw the imminent and natural end of the system. In the next year, it was recommended ${ }^{129}$ that although very few patentees survived, the

123 Sections 2 and 3.

124 Section 4.

125 Section 5.

126 House of Commons, First Report from the Select Committee on Finance (1817).

127 For instance, on the value of such colonial offices, it pointed out that in some cases this depended on fluctuating fees, while for others there were incomplete returns. However, the Committee estimated the annual income then derived from such offices at between $£ 90000$ and $£ 100000$.

128 House of Commons, Report of Select Committee on Sinecure Offices (1833).

129 House of Commons, Report from Select Committee on Sinecure Offices; with Minutes of Evidence and Appendix (1834). Interesting, given the topic of this article, are the observations in this report (at 5-6) on the office of marshal of the Admiralty Court in England. The office, it appeared, was held by the then possessor under a grant during the pleasure of the Crown, while its duties, both of a constant and important nature, were almost entirely discharged by deputy. The Committee recommended that the office be immediately revised and the marshal be required to perform his duties in person. The remuneration from the marshal's office was derived from fees and varied 
abolition of existing patent offices and the provision of a pension for official services in lieu of sinecures should be considered. The figures provided in the last report, ${ }^{130}$ as in the earlier ones, clearly highlighted the demise of the colonial patent office system. In 1812, of seventy-one offices in the colonies, some were sinecures and in others, deputies performed the duties. By 1835, twenty-four had been abolished, thirty had been remodelled and new arrangements made, one was vacant and new arrangements for it were contemplated, and of the remainder, none of which was in any Vice-Admiralty court, only four were held by persons not resident in the relevant colony.

Thus, the system of colonial patent offices came to an end, and was replaced by a professional colonial service, staffed by salaried men who devoted themselves fully to colonial administration.

\section{O'Bryen's appointment as Admiralty marshal at the Cape}

Denis O'Bryen's appointment as marshal of the Vice-Admiralty Court at the Cape of Good Hope in 1806 was therefore a patent office appointment. Throughout the period during which he held the office, until his death in 1832, O'Bryen never visited, let alone resided at, the Cape, ${ }^{131}$ but a succession of deputies performed the duties of the office. This much appears from various official sources, as well as from O'Bryen's own accounts.

As far as the former are concerned, the second report by the Select Committee on Sinecure Offices ${ }^{132}$ in 1811 contains, in an appendix, ${ }^{133}$ a list of colonial offices to which appointments had been made by the Lords Commissioners of the Admiralty, with an indication of whether the duties involved were performed personally or by deputy. In respect of the Cape, there is reference to "Dennis O'Bryen, Gentleman, Marshal, appointed 24 Nov $1806 " .{ }^{134}$ There is no entry for him under the heading

from year to year, sometimes falling short of a reasonable annual salary and at other times greatly exceeding that standard. It recommended that the marshal receive a fixed salary on a scale not more than adequate to ensure the discharge of the duties of the office by a competent person, and that the fees collected be paid over to a government fund. From an appendix (at 11) it appears that the "marshal and serjeant-at-mace of the Admiralty Court" referred to was Hugh Lindsay, appointed in 1815 , and that the emoluments he derived from his office in 1833 amounted to $£ 1200$, subject to the remuneration to be given to his deputy.

130 Report from the Select Committee on Sinecure Offices [in the Colonies and into returns ordered in 1834]; with the minutes of evidence (1835).

131 Even though Philip (n 9) at 307 refers to him as being a British resident there.

132 See $\mathrm{n} 115$ above.

133 Appendix 4 at 89-91.

134 Also listed - as Admiralty appointees - are the Earl of Caledon (as Vice Admiral), Winchcombe Henry Hartley (as judge, also giving details of his salary: see $n 9$ above), William Grey (registrar, in respect of whom alone there was an entry identifying the deputy who executed his office: see 
"by whom [office] executed; and the names of the deputies, where known", but that must be taken to mean that the relevant information was unknown to the Committee at the time, not that there was no deputy and that O'Bryen performed the duties personally. ${ }^{135}$

The Red Book published in $1821^{136}$ contains information on sinecure offices connected to the Cape. It mentions "Denis O'Brien" as "Marshal, Cape of Good Hope" [sic] and notes that his salary was "believed [to be] about £800". ${ }^{137}$

More informative, though, are O'Bryen's own explanations of his appointment. They provide some insight into the surrounding circumstances and his appreciation of the office, the duties it entailed and the benefits it conferred.

further n 174 below), George Kekewick (King's advocate: see again n 11 above), and William David Jennings (King's proctor, appointed in Jun 1809). The information contained in app 5 to the Committee's third report a year later (see n 120 above) is identical, except that it mentioned that the office of King's advocate at the Cape no longer appeared in the latest return. It was further noted that although the Committee had been informed that several of the office-holders listed were at the time resident in the UK, it did not know precisely how many were, because information on residence or non-residence was not required in the returns from the Office of the Admiralty, a further possible explanation the lack of information on O'Bryen mentioned below (in n 135).

135 A footnote explains that whether the various offices were executed by the principal or by a deputy was known only in the instances so noted in the appropriate column, which were ascertained from returns from the respective Vice-Admiralty courts, and which returns were only periodic.

136 See $\mathrm{n} 101$ above.

137 Idem at 190. Earlier editions - 1 ed (1816) and 2 ed (1817) - made no mention of O'Bryen. Other holders of Cape sinecures (not all of whom were necessarily non-resident there) included in the 4 ed were: (1) T Peregrine Courtenay, MP, secretary to the Board of Control, receiving an estimated $£ 750$ in respect of the office of agent [in the UK] for the Cape (at 103); (2) F Dashwood, receiver general at the Cape, earning £4 000 (see also Philip (n 9) at 88-89, mentioning that Francis Dashwood was married to Lady Ann, the daughter of the seventh Earl of Lauderdale, had arrived at the Cape in 1797, was receiver of revenue 1807-1819, president of the Lombard Bank 1808-1814, and collector of customs at Cape Town from 1819) (at 109); (3) James Nagle, suppressed deputy commissary of the Cape, earning £100 (at 187); (4) Lord Charles Somerset, governor, who earned an estimated £14 000; (5) R Spencer, vaccinating surgeon (Philip (n 9) at 397 has Richard Spencer as garrison surgeon at the Cape from 1806, surgeon to the governor's household from 1808, and vaccinating surgeon from 1811 until he left the Cape in 1817) (at 220); (6) JA Truter, who earned $£ 6000$ as Chief Justice and $£ 4000$ as president of the Orphan Chamber (at 232); and (7) "Mr Zeerogel, storekeeper", earning £1 500 (at 248). It must be borne in mind that the information contained in the Red Book was not always correct or complete. In respect of the last-mentioned appointment, eg, the reference is probably to Aegidius Benedictus Ziervogel (1762-1818), a Swedish immigrant, who was interpreter, translator and vendue master in the Cape Vice-Admiralty Court (and probably elsewhere too) from 1800 and again from 1807 . He was the grandfather of EB (Egidius Benedictus) Watermeyer (1824-1867), later a judge in the Cape Supreme Court. 
From a letter ${ }^{138}$ to William Windham, at the time secretary of state for war and the colonies, ${ }^{139}$ written on 11 October 1806, some two months after his appointment in August as Admiralty marshal, it appears that O'Bryen was not quite satisfied and obliquely asked for a further or better appointment in addition to or instead of that one.

He addressed the letter to Windham, although he realised that he obviously had an "abundance of clients for the widest range of your possible patronage". However, O'Bryen explained, the "peculiarities in my misfortune", including the expenses incurred in services rendered to Fox and his party over a period of many years, as well as his advanced age (of fifty-one years) which militated against his seeking a fresh career and fortune, left him no choice but to make such a direct request.

In support of his request for what he termed "proper recompense", O'Bryen referred in his letter to Fox's favourable disposition towards him and to the fact that he had made the same request to Fox ${ }^{140}$ in February 1806. He pointed out, further, that "when Lord Howick gave me the office at the Cape" he had added that although Lord Grenville had nothing further to offer him at the time, as soon as something turned up he (O'Bryen) would have it.

As far as "the Marshalship of the Vice Admiralty Court at the Cape" was concerned, O'Bryen stressed that Lord Howick was aware that he was thankful for it, but "even his Lordship's good will cannot make the office better than its nature admits". The office, he pointed out, in time of peace offered little recompense and even in time of war its benefits were doubtful. ${ }^{141} \mathrm{~A}$ better, but probably still inadequate, ${ }^{142}$ appointment, he ventured to suggest, was to "a sister but superior office in the same court, that of Registrar", the income from which he had ascertained was greater.

138 This letter is included in app 1, item 2 at ii-viii in his Narrative, a pamphlet published around 1820 (see $\mathrm{n} 155$ below for further details).

139 Windham held the post briefly from Feb 1806 to Mar 1807 in Lord Grenville's Whig government. Although he addressed his letter to Windham, O'Bryen suggested elsewhere (see app 4 at xviiixix in his Narrative) that it was aimed "generally at the ministerial survivors of Mr Fox". He alluded in it to the fact that his repeated requests during the previous six months for an answer to his application had produced no response.

140 Also to others who, it seems, had forwarded the correspondence to Windham who had, in turn, asked O'Bryen to state his case. Fox, it should be remembered, died in Sep 1806.

141 O'Bryen was naturally aware that his income from the office depended on fees earned by the marshal and that the Vice-Admiralty Court's main business consisted in the exercise of its prize jurisdiction.

142 He explained that even "if the office of Marshal, inferior in every way, to the Registrar, were equal to the latter in emolument", which it was not, the prospect of getting rid of his financial burdens would not be good. The letter contains several references to his parlous financial state and to the fact that during the previous eight years his general body of creditors had "granted to me three suspensions of all claims", something that had occurred through the intervention of Fox and with the promise that on the change of government his (O'Bryen's) position would change for the better. 
Not having had a response to his earlier request, despite having been assured verbally that the matter would be settled soon, O'Bryen again wrote to Windham some months later, on 10 March $1807 .{ }^{143} \mathrm{He}$ expressed himself "still in hope of a better sinecure appointment" and restated and expanded on his reasons for his request, ${ }^{144}$ and also offered to meet with Windham in person.

O'Bryen's entreaties were to no avail. There were, it seems, other more meritorious or, probably, more influential candidates to be considered ${ }^{145}$ and, in any event, the Whigs were soon out of office.

An aspect of his appointment that clearly troubled O'Bryen was the low financial return from it and the perception held by others that it was in fact a rather lucrative position, at a time when he constantly had to fight off creditors. In a letter to colonel McMahon, secretary to the Prince of Wales, dated 8 March $1809,{ }^{146}$ he wrote that "my patent office, given to me a few days before Mr Fox's death - this grand provision for a life of service, characterized by Mr Fox as 'admitting no competition on the score of merits' - this valuable appointment that was to sweep away the accumulations of near thirty years difficulties and to be the source of solace in approaching age, has yielded to me, in all, from the first hour to this day, no less a sum than two hundred pounds".

A further source of some importance in this regard is the evidence O'Bryen gave to the Select Committee on Sinecure Offices by way of a letter dated 31 March 1811 in response to questions the committee had sent him a few days before. ${ }^{147}$ In a general introductory statement, O'Bryen explained that for his services to the government, he had "received in 1806, towards a compensation", the office of Marshal of the Vice-Admiralty Court at the Cape, and then somewhat sarcastically continued that although he had never foreseen that he would be "over-hauled for my treasures hence", he would nevertheless "in respectful obedience" answer the questions posed.

His answers seem to indicate that O'Bryen had but an imprecise idea of the nature of the office to which he had been appointed, but was fully informed of its financial implications. Questioned on the duties of the Admiralty marshal at the Cape, he merely replied that they were the same as, but of a lesser extent than, those

143 This letter is included in app 1, item 3 at viii-ix in his Narrative (see n 155 below).

144 He referred again to Lord Howick's statement on 12 Aug 1806 that as soon as Lord Grenville had something to give, he would give it to him (O'Bryen), a statement that was made on the very day after his Lordship had nominated him to the office of Admiralty marshal at the Cape and when he was engaged in sending him his thanks. He also mentioned a remark by Lord Grenville that (the by then seriously ill) Fox's mind should be freed from uneasiness on the score of O'Bryen as soon as possible.

145 In May 1807, the office of registrar of the Cape Vice-Admiralty Court was granted to William Grey (see further nn 134 above and 176 below).

146 It is included in Arthur Aspinall (ed) The Correspondence of George, Prince of Wales, 1770-1812 vol 6 (London, 1971) at 371. I thank David O'Shaughnessy for this reference.

147 The questions and O'Bryen's answers are included as app 5 at xx-xxiii in his Narrative (n 155 below). 
of the marshal of the Admiralty Court in Doctors' Commons. He explained that his health, age and private affairs did not allow him to perform any of the duties in person, but that he had availed himself of the power, expressly vested in him by his patent, of providing "a capable deputy". He stressed that that diminished "my own possible gains by a proportionate remuneration to my substitute". He had appointed his deputy himself and in reply to the question whether the appointment had been approved by anyone, he merely and, as will appear, quite prophetically, explained that the nature of this appointment made it probable that the Court "would disapprove of an incompetent delegate". In reply to the question whether he or his deputy had any custody of public money or records, O'Bryen could do no more than respond that he was not aware that any such custody constituted any part of the duties of the office, with the exception of records of the office business. Finally, he indicated that the deputy had given him security for the faithful execution of his deputation, but that he himself had never been asked to give any security.

In regard to the income earned from his office, he stated that neither he nor, as far as he knew, his deputy had ever received one shilling "under the name of salary" as the office did not come with a salary ${ }^{148}$ and he was given to understand "that in peace it is not worth one farthing".

The total amount of all the emoluments he had received in the nearly five years since his appointment in August 1806, was £2 19316 s 3d, of which half had been retained by his deputy. ${ }^{149}$ The emoluments of his office, he explained further, arose entirely from naval captures and not a shilling came from any other source. In addition, the capture of Mauritius in 1810 and the prospect of a Vice-Admiralty court being established there would ensure that his "office necessarily becomes in most strict and liberal sense of the designation, an office sine cura".

On 12 October 1820, at the time when he faced widely reported criminal charges of conspiracy ${ }^{150}$ that had drawn no doubt unwelcome attention to himself, O'Bryen felt obliged to write a letter to the press correcting certain impressions created by earlier reports. One of these was that he held, or had held, "a sinecure place under the present government". ${ }^{151}$ "The only office which I possess", O'Bryen explained, "is a colonial appointment, conferred upon me more than 14 years since by Lord

148 The income to be derived from it depended on the fees collected by the marshal, or his deputy, in the performance of his duties.

149 He pointed out that if the regulations introduced into the Admiralty Court in London (unjustifiably, in his view) had been in force during the whole period of his Cape appointment, he would have received less than $¥ 700$. He further observed that the rights and perquisites of which his office had (contrary to the practice of all other Vice-Admiralty courts) been stripped, had been claimed by his representatives at the Cape, but whether anything would come of that claim depended on the outcome of litigation. I could find no evidence of any such litigation.

150 See, further, $\mathrm{n} 164$ below.

151 See 12 Oct 1820 The Times at 3; the same letter had also appeared the previous day in the Morning Chronicle (see app 2 at ix-x of his Narrative (n 155) below). 
[Howick] (when his Lordship was First Lord of the Admiralty), at the instance of Mr Fox".

However, the attacks continued.

In a reply to this letter the following day, ${ }^{152}$ one Charles Pearson ${ }^{153}$ seemed to suggest that O'Bryen's denial of holding a sinecure office was misleading. "As the place alluded to is a most lucrative situation, and as, if there are any duties belonging to it, they are, or ought to be, performed at the Cape of Good Hope - and as Mr Denis O'Bryen has enjoyed the benefits of the appointment for 14 years, and has not, I believe, been ever near the Cape - I should have conceived myself justified in calling the situation a sinecure place". Nevertheless, he then sarcastically begged O'Bryen's pardon for calling him a "sinecurist" and sought to correct his "error" by admitting that "he fully earns all that he receives".

On 17 October 1820, there was a personal attack on O'Bryen in the House of Commons, ${ }^{154}$ again because of his pending conspiracy trial. In response O'Bryen, perceiving his social and political standing to have been damaged, resorted to his pen and to publication. By the end of November there appeared, in a severely limited run of only six copies, "further circulation ... [to] depend upon circumstances", a pamphlet entitled A Narrative by Mr Denis O'Bryen, in consequence of the attack made upon him by the Hon HG Bennett, in the House of Commons. For present purposes I need only focus on the two observations in it on his patent office appointment. O'Bryen explained that a few days after the death of Fox, on 13 September 1806, a political adversary but personal well-wisher of his in Pitt's administration "stated his regret at my position; warned me of certain disappointment from my post at the Cape; and advised me to ask for a particular situation which he described, being in the patronage of the Colonial Secretary of State". ${ }^{155}$ This explains, therefore, his correspondence to Windham referred to earlier. Elsewhere ${ }^{156}$ he refers again rather disparagingly to "my mockery of an office at the Cape" that he had wished to exchange for "something efficient".

152 See 13 Oct 1820 The Times at 3.

153 Who was involved as "the attorney in the cause" in the prosecution of O'Bryen for conspiracy (see n 164 below).

154 By Henry Grey Bennett (1777-1836), an active and radical Whig MP who was at the time involved in the Whig opposition's planned campaign against civil list expenditures and had obtained details of pensions and other benefits so granted. "He pointed to ministerial involvement in sanctioning the scurrilous letters and publications of Denis O'Bryen and others [Franklin] on the queen [Caroline]": see http://www.historyofparliamentonline.org/volumme/1820-1832 (accessed 26 Jun 2014). For an account of the debate, see, further, House of Commons, Parliamentary Papers, Hansard 2nd Ser vol 3 cols 757-783.

155 At 21.

156 At 47. 
Even in the year before his death, O'Bryen was still bitter about his appointment. In a letter in August 1831, he again observed that it had "turned out to be a mere mockery". ${ }^{157}$

Clearly, then, O'Bryen's patent office appointment as marshal of the ViceAdmiralty Court at the Cape was a great disappointment to him. He had expected, and had been led to believe, that he would receive something worth much more, an expectation no doubt supported as much by his own evaluation of the services he had rendered to the Whigs as by his always-dire financial situation. The fact that he had to defend this disappointment publicly only added insult to injury.

\section{O'Bryen's later life}

A recurring theme throughout his life was Denis O'Bryen's continuous financial distress. He perpetually struggled to escape from the clutches of creditors and by 1806 had already done so on three occasions. ${ }^{158}$ In 1811 the Whig party had to provide him with financial relief ${ }^{159}$ and in 1814 he appears to have landed in the Fleet insolvent debtors' Prison. ${ }^{160}$ In May 1832, only a few months before his death, O'Bryen was again in court as a debtor. The newspaper report of his appearance describes him as someone who "had for many years been in the employment of Government" and who had received up to the last quarter of the Duke of Wellington's administration, ${ }^{161}$ $£ 1400$ a year, and from that time $\$ 500$ a year, but who was now unable to account for the manner in which he had disposed of his property. ${ }^{162}$

O'Bryen continued to be indirectly involved in politics and a supporter of the Whig cause, ${ }^{163}$ not always without serious consequences.

In February 1821 O'Bryen, together with one Franklin, was charged with conspiracy. ${ }^{164}$ The charge involved the production and display of seditious handbills

157 See a letter dated 31 Aug 1831 to Lord Grey, BL Add MSS 51592 fols 53-54, referred to by O'Shaughnessy (n 3) n 13.

158 See $\mathrm{n} 142$ above.

159 See $n 53$ above.

160 See the Fleet Prison returns to the House of Commons of 29 Jun 1814 where the name of "Denis O'Bryen" appears in a list of fees (being a "[c]opy of the printed table of fees hung up in the said prison") paid, since $10 \mathrm{Jul} 1813$, in the Fleet Prison by any person who at the time of the payment was confined there: see (1813-1814) House of Commons, Parliamentary Papers (320).

161 Wellington's administration resigned in 1830.

162 See 24 May 1832 The Times at 4. The report states that although there was some suspicion that a solicitor, Lomax, who had married O'Bryen's niece, had benefited from his connection with the insolvent, that could not be proved, nor could the insolvent's assertion that he had been the victim of a conspiracy.

163 See, eg, 4 Mar 1819 The Times at 3.

164 Details of the trial appear from George Henry Borrow Celebrated Trials, and Remarkable Cases of Criminal Jurisprudence: From the Earliest Records to the Year $1825 \mathrm{vol} 6$ (London, 1825) at 435-443. For further information, see 2 Oct 1820 The Times at 3; 13 Oct 1820 The Times at 3; 18 Oct 1820 The Times at 3 (an editorial); 19 Oct 1820 The Times at 4; 28 Oct 1820 The Times at 3; 
in 1818 and 1819. A warrant was obtained to search O'Bryen's house and on the evidence obtained from a billsticker, a warrant for his arrest was issued on 17 October 1820. Although he voluntarily appeared before a Bow Street magistrate on 18 October, O'Bryen was too ill to be questioned and the examination was postponed. After an indication that the charge against him might be dropped, the matter nevertheless proceeded and O'Bryen and Franklin were brought to trial on 21 February $1821 .^{165}$

While the production and posting of the treasonable placards and Franklin's role were never in question, O'Bryen's involvement was. His defence admitted that while O'Bryen was intimately acquainted with Franklin whom he had received at home, one could not infer the required guilt from that circumstance alone. ${ }^{166}$ Various public figures were then called on to testify to O'Bryen's character. ${ }^{167}$ The jury speedily ${ }^{168}$ returned a verdict of not guilty.

During the 1820s, O'Bryen remained a paid-up member of the Royal Society for the Encouragement of Arts, Manufactures, and Commerce. ${ }^{169}$ For most of the latter part of his life, he resided at various addresses in Craven Street in the Strand. ${ }^{170}$

30 Nov 1820 The Times at 2; 22 Feb 1821 The Times at 3 (an abbreviated law report: $R v$ O'Bryen \& Another); and 23 Feb 1821 The Times at 3 (the full law report).

165 O'Bryen was charged with "conspiracy to excite sedition and disaffection against the person and government of his late and present Majesty; and in order to effect such conspiracy, for having published divers seditious and treasonable handbills and placards, from the year 1818 to the present period" and "conspiracy to vilify and disgrace certain persons who have been distinguished as friends of her Majesty during the late proceedings". Franklin was also charged with treason, but did not plead.

166 The evidence had simply not connected O'Bryen in any way with Franklin's conduct nor had it established any involvement in the production and display of the handbills. Mere knowledge, or even possession, of the placards was not proof of the required guilt or of a guilty connection. Further, the defence pointed out that one of the placards produced in fact contained a "gross attack on the character" of that great statesman, the late Fox, and observed that the jury was quite aware "that Mr O'Bryen had, for a long time, been intimately connected with Mr Fox, and honoured with his friendship. He had been, and still was, on terms of intimate acquaintance with many eminent men, friends of that great man".

167 These included the Duke of Bedford (John Russell, the sixth Duke of Bedford (1766-1839), Whig politician, MP for Tavistock 1788-1790, member of the "ministry of all talents" under Lord Grenville 1806-1807, and father of Prime Minister John Russell, the first Earl of Russell; Russell Square, WC1, was named after the earls and dukes of Bedford who owned the area in the eighteenth century); Lord Holland; Lord Erskine (see n 60 above); and Sir J Macintosh. However, these witnesses could only testify on their knowledge of O'Bryen as a member of the Whig party before 1806, "not having had any acquaintance with him for several years hence".

168 They did not even leave the courtroom but merely "turned round in the box" and consulted together for a few moments.

169 As appears from its annual Transactions during this period, from (1821) vol 39 up to (18311832) vol 48 where his name - "O'Bryen, Dennis, Esq, Craven-street" - appears in the list of contributing members.

170 For details, see GH Gater \& EP Wheeler (eds) Survey of London; Volume 18: St Martin-in-theFields; II: The Strand (London, 1937) at 27-39, ch 4: "Craven Street and Hungerford Lane", 
Ill171 and insolvent, Denis O'Bryen, in life nominally the marshal of the ViceAdmiralty Court at the Cape of Good Hope, died at Margate on 13 August 1832 at the age of seventy-seven years. He is remembered not for his marshalship, but rather for his connection to Charles James Fox, one that ultimately brought him far less than he had expected and hoped for. ${ }^{172}$

\section{Denis O'Bryen's rival and his deputies}

Despite his none too subtle suggestions, O'Bryen was not appointed to the other and more lucrative patent office vacant in the Cape Vice-Admiralty Court at the time, that of registrar. The reason, or at least one of the reasons, was that Lord Howick, who as First Lord of the Admiralty had appointed him to the office of marshal in August 1806, had someone else in mind, someone close to himself and therefore, no doubt, if not more deserving then at least more "appropriate" and "entitled" to appointment as registrar. That someone was his own younger brother, William.

Charles Grey (1763-1845) was known as Lord or Viscount Howick from April 1806 to November 1807. On the death of his father, General Sir Charles Grey (17291807), and as eldest surviving son, he inherited the earldom and became the second Earl Grey. ${ }^{173}$ He was a member of the prominent Scottish Grey family, ${ }^{174}$ which had several connections with the settlement at the Cape.

A younger brother of Charles and third son of Sir Charles, Henry George Grey (1766-1845), was commander of the British forces and lieutenant governor at the Cape from 1807. ${ }^{175}$ In May 1807, Charles Grey, Lord Howick, appointed another

available at http://www.british-history.ac.uk (accessed 10 Apr 2014). In 1820, in a letter to The Times, O'Bryen referred to his " 42 years' residence in this street" (see 12 Oct 1820 The Times at 3). He appears to have left his final residence (at no 21) shortly before his death (see 24 May 1832 The Times at 4, referring to him as "late of Craven St").

171 At the time of the final insolvency proceedings against him, he was reportedly in "a state of apparent imbecility" (see 24 May 1832 The Times at 4).

172 His obituary in the (Jul-Dec 1832) 152 pt 2 Gentleman's Magazine \& Historical Chronicle at 188-189 referred to him merely as "an intimate friend of the Rt Hon J Fox". O'Bryen's political correspondence was sold by auction a year or two after his death and appears to have ended up all over the world. For instance, an undated but autographed letter from O'Bryen concerning his duel with Erskine (see n 59 above) is housed in the Special Collections of the Florida State University Libraries in Tallahassee, Fl (see http://fsuarchon.fcla.edu/inded (accessed 9 Apr 2014)).

173 See, again, $\mathrm{n} 81$ above.

174 See, generally, for what follows, William Courthope (ed) Debrett's Complete Peerage of the United Kingdom ... (London, 1839) at 172-173; Sir Egerton Brydges Collins's Peerage of England ... vol 5 (London, 1812) at 691-693; E Mackenzie An Historical, Topographical, and Descriptive View of the County of Northumberland ... 2 ed vol 1 (London, 1825) at 427-429; Paul David Nelson Sir Charles Grey, First Earl Grey: Royal Soldier, Family Patriarch (Madison, NJ, 1996) passim.

175 Henry George acted as governor from Jan to May 1807, before the arrival of the Earl of Caledon, and again from Jul, after Caledon's departure from the settlement, until Sep 1811, when Grey 
younger brother, William, to the office of registrar of the Vice-Admiralty Court at the Cape. ${ }^{176}$ William Grey (1777-1817), Sir Charles's sixth son, a lieutenant colonel in the army by $1803,{ }^{177}$ received his appointment as registrar from his elder brother in May 1807, such favouritism not going unnoticed, at least in later years. ${ }^{178}$

William Grey occupied the office of registrar until his death in August 1817. Throughout the period of his appointment as registrar, ${ }^{179}$ there was always a deputy at the Cape who performed his duties for him. The deputy registrar from 1807 to 1813 was Henry Buckton, ${ }^{180}$ and from 1813 to 1817 it was George Cadogan, who after that became registrar until $1837 .{ }^{181}$

returned to England (see, also, Philip (n 9) at 155). He should be distinguished from the unrelated Henry George Grey (1812-1898), governor of the Cape 1854-1861.

176 Another brother, Sir Charles's fourth son, George (1767-1828), a flag captain in the Royal Navy 1781-1804 and dockyard commissioner at Portsmouth for twenty-two years (1806-1828), was appointed marshal of the Vice-Admiralty Court at Barbados (see his obituary in (Jul-Sep 1828) 144 Gentleman's Magazine \& Historical Chronicle at 371-372).

177 Nelson (n 174) at 152 observes that when only seventeen and already an army captain, William was created a naval officer of St Lucia through his father's influence and manipulation, which he exercised to advance all his sons' careers.

178 In The Spectator of 31 Dec 1831 at 35, in a piece entitled "Spectator's anatomy of the peerage" "Table IV: General view of the distribution of public money and offices among the peerage and its connections" contains lists showing "how the country may be said to have been occupied by the Aristocracy" and how relatives and connections of peers have taken possession of public money and offices, "both laborious and sinecure". The lists are stated to focus on "that patronage which emanates immediately from the Government". Concerning Earl Grey's family (at 39), "there have been in place" the father, Sir Charles Grey, governor of Guernsey; Sir George Grey, Commissioner of the Navy; Sir George Grey, Admiralty marshal of Barbados; and "the Hon W Grey, Principal Registrar of the Court of Admiralty, Cape of Good Hope".

179 In several sources he is described as being the registrar 1807-1808 and then the "principal registrar" 1809-1817 (see, eg, the listings for the relevant years in the African Court Calendar) and it is possible that he may in fact have been resident here for the first period: see Philip (n 9) at 155 according to whom he "may have arrived on 21 May 1807 in the suit of Lord Caledon in HMS Antelope".

180 Buckton was appointed a notary public, and deputy registrar and also (for a short period: see n 183 below) deputy marshal and examiner of the Cape Vice-Admiralty Court in Jun 1807, and in Mar 1810 he was appointed commissioner for appraisal and sale in the Court. In the second report of the Select Committee on Sinecure Offices (1811) (n 115 above), William Grey's office as registrar is stated to be "executed by Henry Buckton as deputy". Buckton returned to England in Mar 1814, but possibly not permanently as there is mention of a Henry Buckton as a proctor in the local Admiralty Court 1824-1835 and as acting procurator-general 1827-1835 (see Philip (n 9) at 45).

181 Cadogan is mentioned as a proctor in the Court 1809-1813. In Nov 1812, governor Cradock was instructed to recognise him as agent for American (prize) property at the Cape, but in Aug 1813 he was still awaiting his formal commission (see $\mathrm{n} 19$ above). He was appointed notary public at the Cape in Mar 1817 (and had been so appointed in England in 1809) and opened his office at 33 Plein Street in partnership with Francis Lind (see Philip (n 9) at 49). 
What, then, may be said about Denis O'Bryen's deputies at the Cape? Their brief story ${ }^{182}$ is an example, if any were required, of the defects in the colonial patent office system, at least in those cases where the appointee was not resident in the colony in question.

First there was Henry Buckton. Although deputy registrar of the Court, it appears that Buckton also acted as deputy marshal for a short period from June 1807, maybe before O'Bryen could appoint someone to represent him at the Cape. He appears to have occupied the office until sometime in the following year, ${ }^{183}$ when Archibald William Blane became deputy marshal. Blane occupied various offices at the Cape, ${ }^{184}$ but will probably be best remembered for his role as deputy Admiralty marshal in the jurisdictional conflict that arose in the Rosalia matter in May 1808.

More interesting, and possibly the first deputy marshal appointed by O'Bryen himself, was William Bentinck. He, too, held various colonial offices in Cape Town and later became an influential figure in Cape affairs ${ }^{185}$ until his return to England on

182 Background information about the appointments that follow were garnered from the entries of the personnel of the Vice-Admiralty Court under the headings "civil" or "judicial establishment" in the relevant issues of the African Court Calendar (1801-1826); the South African Almanack \& Directory (1827-1839); the Cape of Good Hope Almanack \& Annual Register (1840-1863); the Cape Town Directory (1865-1869); the General Directory of the Cape of Good Hope (1870c1900); as well as from the South African Commercial Advertiser (1824-1856).

183 There is a reference (in a letter from Cradock to Lord Bathurst 17 Apr 1814) to irregular occurrences that took place in Aug 1808, under the Caledon administration, "wherein the name of Mr Buckton, the Deputy Marshal of the Court, is strongly mentioned", irregularities subsequently refuted by George Kekewich (see Theal RCC (n 5) vol 9 at 487-490 and n 12 above). Unless Buckton and his successor Blane's (possibly temporary) appointments as deputy marshal overlapped (or rotated?), the date Aug 1808 may be wrong, given Blane's involvement in the Rosalia matter in May 1808.

184 Blane arrived in Dec 1807, was immediately appointed as a clerk in the colonial secretary's office, took the oath as a sworn translator in Feb 1808 (see Theal RCC (n 5) vol 22 at 451-452), and was appointed in that capacity to the Court of Appeals in Feb 1811. He was also collector of stamp duties from May 1811. Blane left the Cape for Mauritius (where he occupied several governmental posts including those of collector of customs and government secretary: see, eg, idem vol 21 at 268) and thence moved to New South Wales where he became deputy governor of the Australian Agricultural Co. He died in Nov 1852, aged sixty-two years at Booral, Port Stephens (see Philip (n 9) at 32; "Blane, AW" at http://thepeerage.com (accessed 22 May 2014); and his obituary in 17 Nov 1852 Maitland Mercury and Hunter River General Advertiser, NSW, available at http:// trove.nla.gov.au (accessed 22 May 2014)).

185 Bentinck arrived at the Cape from London in Dec 1808 (Theal RCC (n 5) vol 21 at 401) and served as auditor of accounts, later auditor-general, from that time (he was absent on leave for an extended period from 1812) until at least the end of 1827 (see idem vol 6 at 318 and vol 35 at 25). He was also the second member of the Council of Justice from Aug 1814 (see I Farlam "The origin of the Cape Bar" (Apr 1988) Consultus 36), and a member of the governor's Advisory Council from 1825 (see Theal RCC (n 5) vol 21 at 184-185). See, further, Philip (n 9) at 25. 
pension in January 1833. ${ }^{186}$ Bentinck served as deputy marshal in the Vice-Admiralty Court from 1809 until $1812 .{ }^{187}$

The last but most controversial of the four deputy marshals during O'Bryen's tenure was William James Birkwood. He was appointed to the office in March 1812 and as from 1815 was simultaneously the clerk to the collector of customs. This eventually caused problems for both Birkwood ${ }^{188}$ and his principal in London, Denis O'Bryen.

In 1820, a shortfall was discovered in the public revenue "owing to the misconduct and peculation" of "Mr W Birkwood, a clerk in the office of the Collector of Customs". ${ }^{189}$ Birkwood was prosecuted before the Council of Justice at

186 In Jun 1827, on being offered an (a further?) appointment?) as auditor-general at the Cape (at a much reduced salary), Bentinck, then "[o]f all the civil officers sent out from England ... the servant of the longest standing at the Cape establishment" (Theal RCC (n 5) vol 31 at 442-443), replied (from London) that his state of health was such that he could not accept. He had held the position for nineteen years and had also been a member of the Council of Justice (which was about to be abolished) for thirteen years, and a member of the Advisory Council since its establishment. He therefore expressed the wish to retire. His request was granted and he retired on pension (idem vol 32 at 14 and 36; Montgomery Martin (n 48) at 130, mentioning that Bentinck, the "late Auditor-General", received a pension of $£ 500$ in 1832).

187 An interesting aside to Bentinck is that he fathered illegitimate twins, Walter and Portland Bentinck, born 9 Dec 1815 (see "Walter Bentinck" http://www.southafricansettlers.com (accessed 23 May 2014); VC Malherbe "In onecht verwekt: Law, custom and illegitimacy in Cape Town, 1800-1840" (2005) 31 J of Southern African Studies 163-185 at 174). Walter jnr died shortly after birth while Portland was adopted by a local merchant Francis Shortt (himself an interesting and controversial figure as partner in the shipping firm Shortt \& Berry (see, further, Philip (n 9) at 380 on his Cape business activities and on the partners' subsequent fate in Australia; see Barry John Bridges Aspects of the Career of Alexander Berry, 1781-1873 (DPhil thesis, Univ of Wollongong, (1992)). Portland ("Polly") Bentinck, surnamed Shortt (1815-1885), settled outside Pietermaritzburg in Natal on a farm called Shortts' Retreat in the 1840s. The farm became an overnight stop on the ox-wagon route to Durban and became known as Polly Shortt's Place. It is still well known to South Africans as "Polly Shortts", a famous landmark on the Comrades marathon route (see the rather confusing description by Anne Lehmkuhl of the Comrades marathon and the Shortt family in http://archiver.rootsweb.ancestry.com (accessed 2 May 2014)). Francis Shortt should be distinguished from the Scottish military physician Thomas Shortt who was on St Helena at the time of Napoleon's death, attended his post-mortem autopsy in 1821 and drew up the official autopsy report on the cause of his death (see Ben Weider \& Sten Forshufvud Assassination at St Helena Revisited (New York, 1995) at 231, 321, 386 and 395, and Arnold Chaplin A St Helena Who's Who, or a Directory of the Island during the Captivity of Napoleon (London, 1919) at 126).

188 On Birkwood, see Philip (n 9) at 28. On occasion he is referred to as Berkwood. Thus, the ViceAdmiralty Court's mandate, dated Mar 1821, which was addressed by registrar Cadogan to "William James Berkwood Esquire, Deputy Marshal of the Vice Admiralty Instance Court at the Cape of Good Hope", authorised him to serve a copy of the warrant of arrest issued by the Court on the captain of an East Indiaman suspected of having breached navigation and customs laws (see Theal $R C C$ (n 5) vol 13 at 425-426 and 455-456).

189 There had been similar problems in that office before, eg in 1808 when a customs official had retained and used for the settlement of his private accounts, money collected as customs duties 
the instance of the collector of customs Charles Blair ${ }^{190}$ and was ordered to render an account and vouchers for the deficiency. The order was confirmed by the Court of Appeals in January 1822, but in September 1825 when he had not complied with it, Birkwood was condemned by the Council to civil imprisonment, with a view to the final resolution of "this long outstanding Case". ${ }^{191}$

Earlier Earl Bathurst, the secretary of state for war and the colonies, had called on Blair to make up the deficiency. Blair requested a delay so that governor Somerset could explain what had happened. It was also pointed out that it was uncertain whether the security he was required to provide to the amount of the deficiency could be furnished. ${ }^{192}$

Blair also wrote an explanatory "Memorial" to the Treasury in August $1826^{193}$ in which he pointed out that he was being called on to make good a shortfall that arose from the delinquency of a clerk he had not nominated or appointed. He did not

after an express order to pay it in (see Basil James Trewin Leverton "Government finance and political development in the Cape 1806-1834" in (1961) Archives Year Book for South African History 291-359 at 313-314).

190 Blair was appointed collector of customs in Dec 1808 and served in that capacity and as port captain and harbour master until 1820 (see Philip (n 9) at 30-31). Blair himself was not above shady dealings and was in 1825 implicated by the Commission of Enquiry into the Cape in the exploitation for personal gain of the system of "apprenticing" and distributing among colonists the slaves "liberated" from slave ships condemned as prize by the Vice-Admiralty Court. Between Dec 1808 and Dec 1816, twenty-seven ships were thus arrested and brought before the ViceAdmiralty Court and more than 2100 slaves were indentured as apprentices by Blair as collector of customs (see, further, Christopher Saunders "Liberated Africans in [the] Cape colony in the first half of the nineteenth century" (1985) 18 International J of African Historical Studies 223239 at 224 and 226-227; Theal $R C C$ (n 5) vol 19 at 273 and 279).

191 See the letter written on 8 Sep 1825 by the governor Lord Charles Somerset to Earl Bathurst (Theal $R C C$ (n 5) vol 23 at 49-50).

192 See the letter by acting (from Mar 1826-Sep 1828) governor major-general Richard Bourke to Earl Bathurst, 11 Aug 1826 (idem vol 27 at 255-256), pointing out that it was uncertain whether on Blair's death any personal security would be available and that a stoppage of his salary, for which authority of the Treasury would be required, would be the only way to provide security. In another letter, dated 4 Aug 1826, Bourke had explained to Sir Richard Plasket, secretary to the government, that on leaving the colony for England (before Bathurst's letter arrived), Somerset had acquainted himself with every circumstance connected with the matter in order to fully explain Blair's position to both Bathurst and the Lords Commissioner of the Treasury on his arrival in London (idem vol 27 at 256-257).

193 See idem vol 27 at 257-258. Blair pointed out that on arrival after his appointment as Collector of Customs at the Cape in 1808, he had found a clerk and cashier "fixed as part of the establishment". On the death of that officer, the colonial government had named a successor, and on his retirement, it had appointed James Birkwood in April 1815. In November 1819, Birkwood admitted to Blair that there was a shortfall in the cash received from custom dues, in an as yet undetermined amount. Blair then immediately requested a special accountant to examine the books of the Customs House and to report on the amount of the deficiency. This investigation revealed that Birkwood had paid in less than he had collected and received; and that the deficiency amounted to 15098 rixdollars, 4 skillings and 3 stivers in Cape currency. 
consider himself obliged to do so, and the opinions of three eminent counsel (one of whom was the solicitor-general) confirmed his "irresponsibility". In this he was fully supported by the colonial government. ${ }^{194}$

Birkwood himself was dismissed from his customs office by a notice in the Cape Gazette on 19 November 1819, and someone else was appointed in his place.

That caused a problem for the colonial government, however, for Birkwood still held the office of deputy marshal of the Vice-Admiralty Court. The governor approached the Admiralty judge, George Kekewich, concerning the damage that might be done to the Court's name if it retained Birkwood in its employment. ${ }^{195}$

However, Kekewich realised that the crux of the problem was that Birkwood had not been appointed by the Court. He explained "that the Office of Marshal is a patent appointment and that by that Patent the Marshal possesses the sole Power of appointing his deputy". In these circumstances, he did not consider himself competent to remove an officer from the Court in which he presided and "against whom there exists no charge of delinquency". ${ }^{196}$

This left the local government in a quandary. Even if it believed that Birkwood ought to be removed as deputy marshal, it did not wish to interfere with the ViceAdmiralty Court "whose freedom from the control of this Government appears to have been recognized by the opinion of the Attorney General contained in [a] despatch to Lord Caledon" as long ago as March 1808. It was also not clear whether the colonial government itself could suspend the deputy appointed by the holder of a patent office, and if so in what circumstances. ${ }^{197}$ It accordingly informed Kekewich in August $1826^{198}$ that it had referred the matter to London for advice and instructions.

Some months later, in June 1827, the secretary of state replied that the Lord High Admiral, when the matter was referred to him, had ordered Birkwood's dismissal from his office of deputy marshal of the Vice-Admiralty Court at the Cape of Good

194 Thus, on 17 Nov 1826, with reference to a letter from Bathurst enquiring whether he wanted to make any representation on Blair's liability to make good the shortfall, governor Somerset replied that he had the strongest grounds for considering Blair to be "a gentleman of the most rigid honour and integrity" and that the deficit in question had "occurred solely from the dishonesty of a man who had the art to obtain Blair's fullest confidence which he basely betrayed" (idem vol 28 at 329-330).

195 See the letter of 22 Aug 1826 from Richard Plasket, government secretary, to Kekewich (idem vol 27 at 332) and the letter of 6 Sep 1826 from major-general Richard Bourke, acting governor, to Earl Bathurst (idem vol 27 at 330-331).

196 See the letter of 24 Aug 1826 from Kekewich to government secretary Sir Richard Plasket (idem vol 27 at 332). From this, it is not clear whether Kekewich would have removed Birkwood if there had been a charge.

197 See the letter of 6 Sep 1826 from major-general Richard Bourke, acting governor, to Earl Bathurst (idem vol 27 at 330-331). Bourke stressed, however, that in the Cape colony it would be "peculiarly inexpedient to retain a defaulter in the public service".

198 See the letter of 31 Aug 1826 from Plasket to Kekewich (idem vol 27 at 333). 
Hope. ${ }^{199}$ In London the Admiralty informed the Colonial Office accordingly, ${ }^{200}$ and later also informed it "that it appears by a communication from the Marshal of the Vice-Admiralty Court at the Cape of Good Hope [ie, from Denis O'Bryen], that he will as soon as practicable dismiss Mr Birkwood from his office of Deputy Marshal of that Court, and appoint another in his room". ${ }^{201}$

Whether O'Bryen in fact ever did dismiss his deputy Birkwood, or whether the Admiralty's order in this regards sufficed, is not clear. A new marshal was appointed only in $1837,{ }^{202}$ another indication that at the time the Vice-Admiralty Court was certainly not very busy. Of Birkwood himself little is known, except that he died in July 1847 at the age of $68 .{ }^{203}$

\section{O'Bryen's successors and the end of the Vice- Admiralty Court}

After the patent office appointment of Denis O'Bryen came to an end on his death in 1832, some five years elapsed before the office of marshal of the Cape ViceAdmiralty Court was filled.

James Bance was appointed in July 1837 in the place of O'Bryen ${ }^{204}$ and served as Admiralty marshal until 1852. He was a retired lieutenant in the Royal Navy ${ }^{205}$ and had also been, from 1826, the port captain at Cape Town, ${ }^{206}$ which was no doubt his main appointment. Married to the eldest daughter, Sarah, of influential local businessman and politician John Bardwell Ebden in 1828, ${ }^{207}$ Bance was well connected until his death in 1866 at the ripe old age of eighty-four years.

199 See the letter of 6 Jun 1827 from secretary of state, Viscount Goderich, to acting governor Bourke (idem vol 30 at 441 ).

200 See the letter of 12 Jun 1827 from John Barrow, who was at the Cape from 1797-1804 and who was subsequently second secretary to the Admiralty 1804-1844, to RW Hay, who was permanent under-secretary in the Colonial Office from 1825-1836 (idem vol 30 at 524).

201 See the letter of 21 Jun 1827 from Barrow to Hay (idem vol 32 at 35).

202 Birkwood's name still appears as deputy marshal in the 1831 South African Almanack.

203 See Jul-Sep 1847 South African Commercial Advertiser.

204 The (Jan-Apr 1838) 25 (NS) Asiatic J and Monthly Register at 47 (in its Register) announced that on 20 Jul 1837 "lieut James Bance, RN" had been appointed to be marshal of the Vice-Admiralty Court of the Cape of Good Hope "in room of Mr Dennis O'Bryan dec. (appointed by Lords Commissioners of the Admiralty)".

205 See William R O'Byrne (ed) A Naval Biographical Dictionary (London, 1849) at 44 for his full naval career.

206 See Theal $R C C$ (n 5) vol 23 at 493; vol 24 at 63 and 139; vol 28 at 491; vol 30 at 55-56 (where he is described as "zealous, active, intelligent and economical") and at 70 (where it is explained that on the appointment of Bance as port captain, the existing office of deputy port captain had been abolished altogether).

207 See http://www.geneall.net (accessed 22 May 2014).They had ten children. On Ebden, see Marian George "John Bardwell Ebden, his business and political career at the Cape, 1806-1849" in (1986) no 1 Archives Year Book for South African History 1-99. 
Next came Daniel J Cloete, marshal for a brief period from 1853 until 1856, who was also, significantly, high sheriff of the Supreme Court. ${ }^{208}$ Apart from his own judicial connection, Cloete's brother was Judge Hendrik Cloete while his daughter Janette married $\mathrm{Mr}$, later Judge, Cole. ${ }^{209}$

Henry Walker, of whom little is known, ${ }^{210}$ was the next marshal, until 1873. Significantly, during his tenure of office, there was again a deputy marshal, Samuel Bushell. ${ }^{211} \mathrm{He}$ was appointed in that capacity in 1864 and is mentioned until at least 1878. ${ }^{212}$

In 1874 another naval man, Jan Marthinus Hoets, ${ }^{213}$ was appointed to the office, but appears to have served only until 1878. A well-to-do businessman at the Cape, ${ }^{214}$ he was also involved in various shipping matters, for instance as a ship surveyor. ${ }^{215} \mathrm{It}$

208 This may have been another step, or at least have aided, in avoiding the jurisdictional conflict between the two courts (see at n 22 et seq above). See further, eg, the advertisement of the sale of a ship, in execution of a Supreme Court judgment in Jul 1853, signed by "Daniel J Cloete, High Sheriff" (http://archiver.rootsweb.ancestry.com (accessed 26 May 2014)); (Apr-Jun 1854) South African Commercial Advertiser in which the marriage on 9 May 1854 is announced of the eldest daughter of "Daniel J Cloete Esq, High Sheriff of the Colony".

209 See F St LS "The Honourable Mr Justice Alfred Whaley Cole" (1935) 52 SALJ 1-11 at 10, referring to "Mr DJ Cloete, for many years Deputy Sheriff and brother of Judge Cloete and genl Sir AJ (Josias) Cloete". It is unclear whether our Cloete was the "DJ Cloete" whose insolvent estate resulted in litigation at various times. See Ebden v Anderson (1854) 2 Searle 64 (where the trustee of DJ Cloete's insolvent estate had transferred immovable property to the plaintiff in Jun 1851) and In re Cloete, Ex parte Jones (1881) 1 SC 85 (which concerned the insolvent estate of DJ Cloete of Cape Town, "since deceased", that had been surrendered as insolvent in Nov 1849, for which a discharge had been obtained in Oct 1850, and that again became insolvent in Dec 1870).

210 A daughter of "Henry Walker" was christened in Mar 1843 (see Jan-Mar 1842 South African Commercial Advertiser); his youngest son died in Nov 1855 (see Oct-Dec 1855 South African Commercial Advertiser); and Walker v Executors Walker (1874) 4 Buch 144 concerned an action to set aside and have declared invalid the will of "the late Henry Walker".

211 Bushell, who was born in Dover in 1811 (see http://www.southafricansettlers.com (accessed 23 May 2014)) and whose son was born in Jul 1854 (see Jul-Sep 1854 South African Commercial Advertiser), died on 27 Sep 1894 at the age of seventy-three (according to his gravestone in the Mowbray Old Cemetery, Cape Town (see http://www.eggsa.org (accessed 23 May 2014)). It is a statistical aberration, surely, that all five deputy Admiralty marshals at the Cape bore surnames starting with "B".

212 There is also mention of a WM Jennings as deputy Admiralty marshal in Port Elizabeth in 18721873.

213 Captain Hoets (1821-1881) was married to the daughter of John James Centlivres Chase, an 1820 British settler and attorney and notary at the Cape (see, further, http://southafricansettlers.com (accessed 28 May 2014) and (Sep-Dec 1836) 21 (NS) Asiatic J and Monthly Register at 117). There is a photo of Hoets and his wife at http://www.myheritage.com (accessed 27 May 2014).

214 He was, eg, Turkish vice consul in Simon's Town (see Tom Wheeler Turkey and South Africa: Development of Relations 1860-2005 (South African Institute of International Affairs Report no 47, nd) at 4); and donated fish specimens to the South African Museum (see the Catalogue of the Specimens in the Collection of the South African Museum. Part I: The Mammalia (Cape Town, 1861) at 82).

215 Early in 1864, Hoets surveyed and wrote a report on the American Confederate bark Tuscaloosa, 


\section{DENIS O'BRYEN ...}

may well have been that he accepted the appointment as Admiralty marshal at a time when his own business fortunes were on the wane. ${ }^{216}$

The last marshal of the Cape Vice-Admiralty Court, from 1881 until 1891, was Hugh Marchant Penfold, again a retired naval officer. A nautical assessor at the Cape and also port captain ${ }^{217}$ for seventeen years, Penfold was a friend and roommate of Cecil John Rhodes. ${ }^{218}$ He retired in 1896 for reasons of ill health. ${ }^{219}$

In 1891, the system of British Vice-Admiralty courts in colonial possessions came to an end. Vice-Admiralty courts were abolished and in most cases the local Supreme Court was endowed with Admiralty jurisdiction. This was in terms of the Colonial Courts of Admiralty Act, $1890^{220}$ which was passed in July 1890 and which, with a few exceptions, came into force in every British possession, including the

the Alabama's tender and formerly a Union vessel Conrad captured as a prize by the Alabama. The bark and her equipment and cargo were controversially allowed to enter Simon's Town for repairs and supply (see my "The story of the CSS ("Daar kom die ...") Alabama: Some legal aspects of her visit to the Cape of Good Hope, and her influence on the historical development of the law of war and neutrality, international arbitration, salvage, and maritime prize" (2007) 13 Fundamina 175-250 at 201 and 207-210). The report, dated 13 Jan 1864, was forwarded by the US consul Walter Graham, who had appointed Hoets for that purpose, to governor Wodehouse (see US Dept of State Correspondence concerning Claims against Great Britain vol 4 (London, 1869) at 240 241). Ten years later, in Gifford $v$ Table Bay Dock and Breakwater Management Commission, The China (1874) 4 Buch 96, Hoets gave evidence in a matter concerning the liability of the harbour board for a ship that had fallen off a patent slip. He declared (at 101-102) that he had "assisted at slipping a good many vessels at the Simon's Town patent slip". He conceded that nobody might have been to blame for the accident, but observed that "[s]hips ought to be insured against risks of this sort". See also Poultney v Van Santen (1874) 4 Buch 76, from which it appears that Hoets was a ship surveyor in Simon's Town.

216 See Anderson \& Co v Hutton \& Co (1875) 5 Buch 73, in which it appeared on the sequestration of his partnership with John Thomas Hutton in a shipping and landing agency, that Hutton had attended to the paper work while Hoets performed all the outdoor work; and where it was accepted that unlike Hutton, "Hoets honestly, diligently and labouriously [sic] attended to his department".

217 In which capacities he signed the findings of courts of enquiry held in Cape Town into marine accidents.

218 Penfold was born in London in 1840 (see Armorial Families: A Directory of Gentlemen of CoatArmour, 1905 vol 5 at 1073 available at http://www.movaco.com (accessed 14 Apr 2014)) and came to the Cape at an unspecified date (his second son was stillborn in London in May 1876, and he divorced his second wife in Cape Town in 1885). He shared quarters with Rhodes in Adderley St and taught him to yacht, and it was through Rhodes's intercession that he was appointed as port captain (see "Marchant Penfold (1): Genealogy" at http://www.werelate.org (accessed 14 Apr 2014); and "Marchant Hugh Penfold (1840-1902) - Genealogy" at http://www.geni.com (accessed 14 Apr 2014)).

219 Penfold suffered from asthma and Rhodes sent him to Kimberley to become a director of the De Beers Consolidated Mining Co. He was involved (trapped) in the siege of Kimberley (ibid). He returned to Cape Town where he died in Mar 1902 (see his gravestone in the Maitland Cemetery, available at http://www.eggsa.org (accessed 23 May 2014)).

22053 \& 54 Vict c 27. The Act is reproduced in (1890) Cape JL 241-252. See, generally, DG Scott "Admiralty jurisdiction in South Africa prior to 1983" (2002) 7 Fundamina 204-212. 
Cape, on 1 July $1891 .^{221}$ As from the latter date, it abolished existing British ViceAdmiralty courts in the colonies, ${ }^{222}$ including, therefore, the Vice-Admiralty Court of the Cape of Good Hope.

In the place of the abolished Vice-Admiralty courts came colonial courts exercising an Admiralty jurisdiction. They were to be called Colonial Courts of Admiralty. ${ }^{223}$ These courts were part of the ordinary local judicial system - in practice they were the local Supreme Court or its equivalent - and as such independent of any Imperial control. In short, in 1891 the system of British Vice-Admiralty courts was replaced by one of local Admiralty courts.

As regards the Admiralty marshal, an officer of the local Supreme Court ${ }^{224}$ then performed the relevant duties where the court exercised that jurisdiction.

\section{Abstract}

Denis O'Bryen's appointment as marshal of the Vice-Admiralty Court at the Cape of Good Hope in 1806 resulted from his political activism in England during the preceding decades. It must be understood in the context of the system of colonial patent office appointments that operated at the time.

221 Section 16. The exceptions were provided for in sched 1.

222 Section 17. Specific provision was made for pending proceedings and appeals. In terms of s 9(1), the power was retained lawfully to establish (or re-establish, in the case of abolished courts) ad hoc Vice-Admiralty courts "by commission under the Great Seal".

223 Section 2(1) of the Act provided that every court of law in a British possession which had been declared under the Act to be a court of Admiralty, or if no declaration was in force in the possession, every court with "original unlimited civil jurisdiction", would be a court of Admiralty. It would exercise the jurisdiction mentioned in the Act, and would in respect of such jurisdiction be referred to in the Act as a Colonial Court of Admiralty. Accordingly, in the Cape, where there was no such declaration, the Supreme Court became a Colonial Court of Admiralty when called upon to exercise its Admiralty jurisdiction.

224 Hercules Tenant, high sheriff of the Cape Supreme Court from 1889, was, somewhat belatedly but no doubt in response to the outbreak of the South African War, appointed in 1899 by the Court as marshal "under its admiralty jurisdiction" (see Anon "Mr Hercules Tenant, CMG" (1909) 26 SALJ 341-344 at 343). 